Article

\title{
Rock Art Research in Southeast Asia: A Synthesis
}

\section{Noel Hidalgo Tan}

Archaeology and Natural History, School of Culture, History and Language, College of Asia and the Pacific, The Australian National University, Canberra, ACT 0200, Australia; E-Mail: noel.tan@anu.edu.au or seaarch@gmail.com; Tel.: +61 404413883

Received: 4 October 2013; in revised form: 29 January 2014 / Accepted: 29 January 2014/ Published: 13 February 2014

\begin{abstract}
Rock art has been known in Southeast Asia since the early 19th century, but relatively little attention has been paid to this class of archaeological material. This paper attempts to correct the perception that there is little rock art known in the region; especially in the light of intensified research efforts over the last 30 years that have led to the discovery of numerous new sites. Over a thousand rock art sites are known in the form of rock paintings, petroglyphs and megaliths in Southeast Asia, and their distribution across the various territories are uneven. This paper summarises the state of rock art research in Southeast Asia and discusses some of the challenges of studying rock art in this region, research trends and new finds from recent research.
\end{abstract}

Keywords: rock art; Southeast Asia; Thailand; Myanmar; Cambodia; Laos; Vietnam; Malaysia; Philippines; East Timor; Indonesia; Singapore

\section{Introduction}

Rock art has been reported in Southeast Asia since the 19th century [1-4], but mentions of Southeast Asia in the context of world rock art have been scant at best. Until recently, relatively little research has been done in Southeast Asia, leaving one with the impression that there is little or no rock art in the region. Up until the 1980s, only a handful of sites were known, including Liang Lumba in Kalimantan [3], Khao Khian, Pha Mue Daeng and Tham Roob [5-7] in Thailand, several Indonesian sites named by van Heekeren [8,9], Gua Tambun in Peninsular Malaysia [10,11], the Painted Cave (Gua Kain Hitam) in Malaysian Borneo [12] and the Padahlin Caves in Myanmar [13]. In 1987, during a meeting of prehistorians in Bangkok at Southeast Asian Ministers of Education Organisation Regional Centre for Archaeology and Fine Arts (SEAMEO-SPAFA), a discussion recorded at the end 
of the seminar suggested that rock art was not a viable field of research: "Given their scarcity and the difficulty of interpreting them, are rock paintings a profitable subject for future research? [14]" It should be noted that SEAMEO-SPAFA has since recognised the importance of rock art research in Southeast Asia, having organized several interdisciplinary workshops bringing together professionals in the regional community since 2011 .

With the exception of a review by Taçon and Tan [15], the most recent comprehensive overview of rock art in Southeast Asia was written by Kusch [4], mentioning over 30 rock art sites; however, his work was not widely known, as evidenced by the lack of reference from later authors. Anati's [16] book, World Rock Art, acknowledges the gap of knowledge in that region, displaying absolutely no Southeast Asian sites in his map of the world. Jean Clottes's [17] book, also entitled World Rock Art, slightly improved the situation by representing Southeast Asia with a single page, featuring a site from Borneo that contained hand stencils. In the 2001 Handbook of Rock Art Research, Southeast Asian rock art is limited to a three-page discussion in a larger chapter about the rock art of Asia [18]. Chen discusses rock art sites in Malaysia, Indonesia, Thailand and Myanmar, although most of the works cited were published prior to 1980. Bellwood and Glover's [19] textbook on the archaeology of Southeast Asia paints a similar image about the scarcity of rock art in the region: "Of art we have little, especially compared to the rich cave tapestries of northern Australia, but (...they) do occur in caves and rockshelters across the region." Thus, the available English-language literature gives the impression that very little rock art exists in the region.

Two factors obscure our knowledge of the rock art of Southeast Asia. Firstly, rock art is still a relatively new research focus in the archaeologies of the region. Neither Southeast Asia nor any of its constituent countries are currently represented in the International Federation of Rock Art Organisations (IFRAO). As many countries in Southeast Asia are still developing, archaeology does not enjoy a high priority in the national agenda, and rock art, when mentioned, often forms part of a larger report about excavations in a particular cave or region. Thus, most reports tend to treat rock art in a fairly descriptive manner, often laced with fleeting interpretations that are more speculative than objective. The second factor is related to the academic landscape of the post-colonial present-many archaeological reports written in the region today are not published in widely distributed English-language journals, but are written in small local journals with limited circulation, and in local languages which further limits dissemination. For example, following a sustained rock art recording programme in Thailand from the 1980s, the Fine Arts Department has published a number of books about the rock art of several regions in the country (see [20-26]). These books are written almost entirely in Thai, and are typically sold at local museums and therefore generally unavailable to non-Thai readers and readers outside of Thailand.

In this survey of the rock art in Southeast Asia, I define rock art as anthropogenic markings on stone; most commonly in the form of rock paintings (pictograms) and engravings (petroglyphs). I also include in this discussion megaliths as a class of rock art, given that like pictograms and petroglyphs they are considered as a form of landscape art and in many cases megaliths themselves contain petroglyphs. Given linguistic constraints I have drawn primarily on English-language publications for this survey, and where accessible, local-language reports. Secondary sources such as museum displays, unpublished reports and concurrent research have also contributed to this paper. 
To facilitate discussion of a wide corpus of sites spanning multiple countries, I have limited the discussion to the traditional geopolitical boundaries of Southeast Asia: east of India, south of Hong Kong, north of Australia and west of Papua New Guinea. It is important to note that some of these peripheral areas-particularly southern China and northern Australia-contain rock art that have affinities to the area in discussion (see further discussion of recent research in [15]), but under the constraints of space I concentrate on two regions: Mainland Southeast Asia and Island Southeast Asia, under the current geopolitical boundaries. In both areas, evidence for prehistoric human activity is to be found mainly in caves and rock shelters in the form of stone tools of varying traditions. In fact, caves and rock shelters continue to be used for various purposes, including habitation, burial and worship. As in many other places in the world, one marker for the human use of caves is the presence of rock art.

\section{Mainland Southeast Asia}

The region discussed as Mainland Southeast Asia comprises the modern nation-states of Thailand, Cambodia, Laos, Myanmar, Malaysia, Vietnam, and Singapore. It is geographically, linguistically and climatically diverse: home to several mountain ranges, including the lower Himalayas in northern Myanmar and the Dangrek chain bordering Thailand and Cambodia. A total of some 270 million people who speak a mixture of Austro-Asiatic, Thai and Austronesian languages currently live in the region.

\subsection{Thailand}

The Kingdom of Thailand has one of the most developed archaeological programmes in the region, due to sustained archaeological research through the Fine Arts Department. The country's stability and prosperity relative to many of her neighbours has also led to a number of foreign-led archaeological projects conducted within her borders; hence much of our knowledge of the prehistory of Southeast Asia is derived from Thai discoveries.

In total, there are at least 200 documented rock art sites in Thailand [28], although most of the published information appears in Thai (e.g., [20-25]). The vast majority of rock art in Thailand are pictograms painted in monochrome red [29]. The distribution patterns of rock paintings, particularly the presence of strong clusters in the north, northeast, central and southern offer potential for future studies in spatial and geographic distribution of human populations and activity. These regions will be discussed in turn.

Archaeological research in northern Thailand began in the 1960s and 1970s in Pang Mapha Province. Rock paintings sites have been discovered in the northern provinces of Mae Hong Son, Chiang Mai and Lampang. These paintings have been commonly dated to between 3,000-5,000 years BP, but no chronometric dating has yet been undertaken [29]. In Mae Hong Song province, eight rock art sites are known in the Pang Ma Pha district depicting a variety of designs in red pigment, except for a single polychromatic painting in Tham Lod, which is unique in Thailand [29]. Ban Rai, a rock shelter in the same district that was re-investigated in the last decade contains rock paintings of human figures and animals around a central circular image [30]. The art was previously documented by Sawatsalee [31], who concluded that the paintings depict human relations to the landscape. In Chiang Mai Province, Pha Phung and Pha Mai are both honey-collection sites that contain the same depiction of a 
three-toed zoomorph [29]. The paintings at Phra Tu Pha in Lampang province are at the base of a limestone cliff and encompass an area over $300 \mathrm{~m}$ long. Over 1,800 paintings have been identified, over half of which are hand prints [27,29,32-34]. Elsewhere in Northern Thailand, the sites have been noted in Hot, Chiang Mai and Lampang provinces [35-37]

The rock art of Northeast Thailand was the focus of a concentrated research effort in the early 1980s. Higham and Thosarat [38] make an observation on the site of Khao Chan Ngam, at the western edge of the Khorat Plateau which contains red-pigmented paintings of a hunting scene (Figure 1). A pictogram interpreted as a dog would establish a relative chronology within the last 4,000 years since dogs do not turn up in the archaeological record before then (see also [26]). Another key site, Pha Taem, lends its name to the national park in Ubon Ratchathani province. The rock art is located on cliff faces overlooking the Mekong river, the largest of which contain depictions of catfish, elephants and anthropomorphized figures [38]. Also in Northeast Thailand is the Phu Phra Bat Historical Park in Udon Thani Province. Phu Phra Bat has a long history of usage from prehistoric times and contains a number of paintings along the walls of the rock formations; the best preserved depict men near a group of bullocks, which may infer some sort of animal husbandry activity although from my own observation of the site these two panels are unrelated. Due to the depiction of domestication these paintings have been estimated to date between 4,000-2500 BP [22,40]. Chen [18] suggests a possible connection between the rock art in Cangyuan, in Yunnan province of Southwest China and the art in northeast Thailand. He suggests that this connection, if further explored, might hint at the human migration from China to Thailand. There is not enough space for a discussion of the rock art of Yunnan and other parts of China bordering Southeast Asia, but it suffices to say that several sites lie in close proximity to geopolitical Southeast Asia that can be considered as part of mainland Southeast Asia as a region [41-47].

Figure 1. A "hunting scene" from Khao Chan Ngam in Nakhon Ratchasima province. The presence of a dog suggests that the rock art is less than 4,000 years old. Photo: Noel H. Tan.

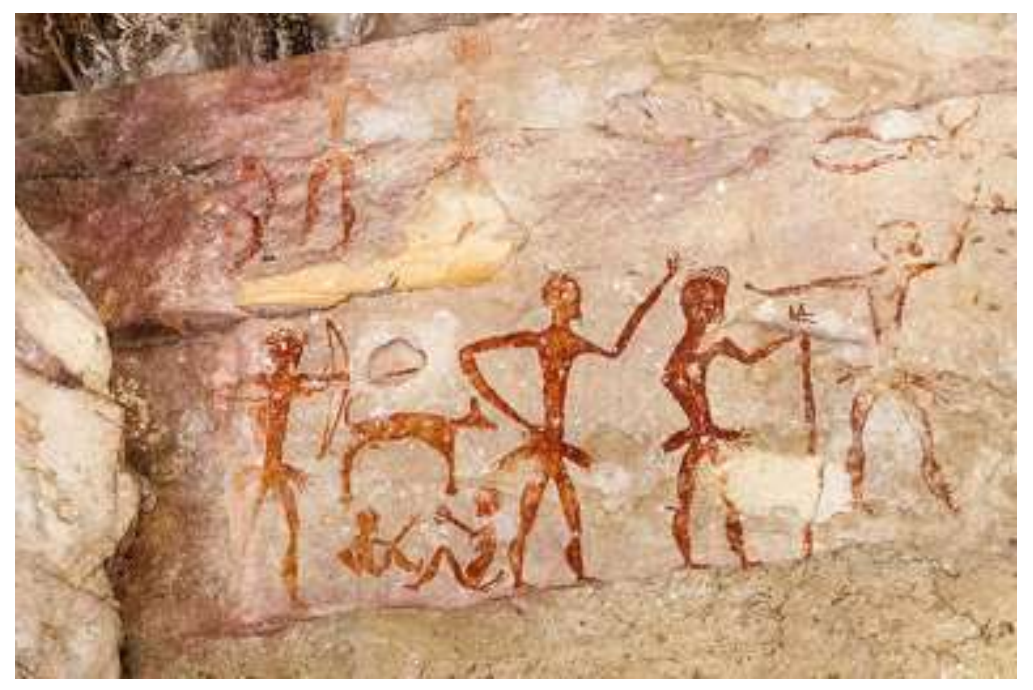

Rock art in central Thailand is relatively sparse, but several sites have been mentioned in literature, such as Tham Pha Daeng and Tham Ta Duang in Kanchanaburi province. The former includes a 
depiction of a "kilted" man wearing a headdress and costume embellishments interpreted as feathers, while the latter contains a depiction of a circular drum [38,48]. Tham Roob, another site in Kanchanaburi province, discovered by the Thai-Danish expeditions between 1960 and 1962, contains depictions of a "reptile" figure that was observed as a tattoo motif used by the living populations in the area, which may allude to some ethnographic connection between the rock paintings and the indigenous population [49]. In Uthai Thani Province, the mountain of Khao Plara contains red and black paintings on a west-facing cliff side [50]. A recently completed MA thesis by Victoria Scott from the School of Oriental and African Studies looked at the rock art of Tham Ta Duang, Khao Daeng and Khao Plara in Kachanaburi and Uthai Thani Provinces, assessing various theories about the rock art and concluding that the rock art depicted some sort of ritual activity [52].

Southern Thailand is known for the first discovery of rock art in Thailand, at the site of Khao Khian in Phang Nga province, which was reported by Lunet da Lajonquière in 1912 [7]. In the 1980s, some 48 prehistoric sites were investigated by the Southern Thailand Archaeological Research Project [51,53]. Several isolated rock art sites have been identified: Tra Cave in Trang Province is known to date to the historical period while Dong Ao Rusi in Satun Province may derive from a prehistoric context, but to date no further work or information has been published about it and the nature of the rock paintings there are unknown. By far, the heaviest concentrated area of rock paintings lie in the coastal limestone formations of Krabi and Phang Nga provinces, which have been dated to 2,000-3,000 years ago on the basis of associated stone tool finds [53]. These sites contain numerous predominantly red-pigment rock paintings. Many of these sites are scattered throughout the islands in the bay, and contain depictions of anthropomorphs; zoomorphs identified as fish, birds and mammals; and geometric designs. The largest of the Phang Nga Bay sites include Ko Phra Ard Tao in Phang Nga province, a limestone cliff with paintings in an area over $100 \mathrm{~m}$ long depicting humans and fish; Tham Phi Hua To in Krabi province, which contains approximately 40 paintings of anthropomorphs, zoomorphs, hand prints and other abstract designs spread throughout two chambers; and Tham Reussi in Phang Nga province, which contains red-pigment rock art [54]. To the south of Phang Nga Bay, the island sites of Ko Pi Pi Don, Tham Phayanak, and Ko Rang Nok contain depictions of European-style sailing ships that indicate a relatively recent age, painted in the last 200-400 years [20,55-57] (Figure 2). The other coastal sites along the Phang Nga and Krabi Bays are thought to be much older and belong possibly to pre-agricultural societies.

Recent studies have opened up research into the rock art of South Thailand, such as sites from the historic era, particularly on the cave temple sites used by Hindus and Buddhists. To date, there are 13 such rock art sites in Southern Thailand distributed from Chumphon province in the north to Yala province in the south dating from the 7th century until the early 20th century. The rock art from this period is likely imported from Hindu and Buddhist traditions of using caves as sacred spaces. The earliest caves from this historic period contain similarities with Hindu cave temples in India, while later rock art expressed Buddhist styles from the Dvaravati period (c. 9-10th century) up to the recent Rattanakosin period (1851-1932) [58]. More recently, Sukkham reported two rock painting sites in Yala province, Yala Mountain and Silpa Cave which contain red and black pigment rock art respectively [59]. In 2010, Sukkham completed his MA research at Silpakorn University on the rock art of southern Thailand which involved the re-recording of 23 sites [60]. The sites consist of painted rock shelters and cave walls along the west coast and mountainous areas of southern Thailand and are 
thought to date to between 4,000 to 2,000 years BP, though direct dating has not been undertaken. Historic period sites of southern Thailand are of various types, containing paintings, sculptures, inscriptions and/or engravings.

Figure 2. Tham Phrayanak in Krabi province contains many depictions of ships from several cultures. Photo: Noel H. Tan.

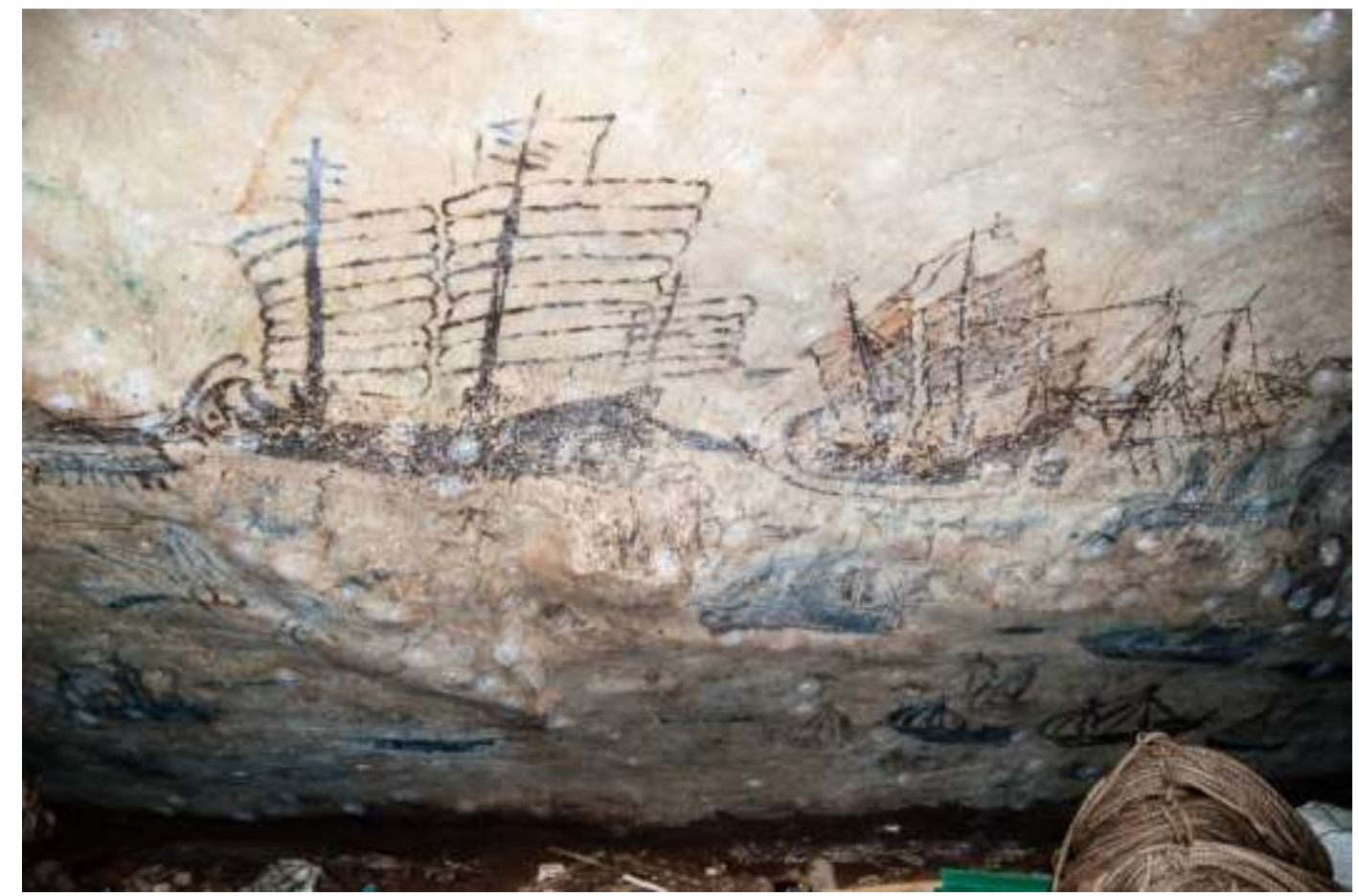

Thailand's rock art spans a large diversity of types, styles, periods and forms. In contrast, very little is known about the rock art in neighbouring countries, but her central location in Mainland Southeast Asia hints at the amounts of rock art that possibly exists and remains to be discovered.

\subsection{Cambodia}

Until very recently, rock art was unknown in the kingdom of Cambodia. In the last decade, however, a number of rock art sites have been discovered in different parts of the country, leading to renewed interest. The first recording of Cambodian rock art was in 2007 from the Cardamom Mountains on the west of Cambodia, near Kanam Village in Pursat Province [61,62], bordering Thailand; Poeung Kamnou is a painted boulder containing 45 paintings, consisting mostly of animals such as elephants, water buffalo and deer, in addition to agricultural tools. Archaeological research at the Cardamom Mountains is ongoing (see [63]) and it is expected that more art sites will be discovered.

More significantly, a number of rock art sites have recently been discovered at the Phnom Kulen area of Siem Reap province, near the world heritage-listed Angkor Archaeological Park. The rock art was discovered during a ground survey conducted by the Authority for the Protection and Management of Angkor and the Region of Siem Reap (APSARA) for the Living Angkor Road Project [64,65]. The art sites were documented during another survey in 2011 [66] where a total of 10 were identified. Most 
of these sites were painted sandstone rockshelter sites containing red paintings depicting animals and other abstract figures. They are presumed to be of a prehistoric age, due to their rockshelter context and use of red ochre as pigments, but none can be regarded as securely dated at this point in time. A number of Angkoran sites in Phnom Kulen can be considered as rock art sites, because they consist of modified stone landscape features. The most famous of these is Kbal Spean, a riverine site with depictions of the reclining Vishnu carved on the rocks, and the River of a Thousand Linggas, in which sections of the river bed have been carved with numerous stumps or linggas, which represent the phallic power of the Hindu deity Shiva. Poeung Tbal is another carved boulder depicting the reclining Vishnu. Elsewhere on Phnom Kulen, Srah Tamri is an unusual site consisting of large boulders carved in the shape of an elephant and simhas (lions) [67].

My current research at the Australian National University looks at two of these sites at the Phnom Kulen area, Poueng Komnou (Born Gamnur in [67]) and Poeung Ta Khap. Poeung Komnou is a sandstone boulder located in the eastern foothills of Phnom Kulen. The boulder contains several bas-relief carvings of the deities Vishnu and Ganesha, and inscriptions indicate that it was used as a hermitage in the 12th century [68] (Figure 3). The aforementioned Living Angkor Road Project noted the presence of red pictograms at the same site, indicating a long history of human activity at the site. Poeung Ta Khap was a recently discovered site by the Archaeology and Development Foundation project on Phnom Kulen; it is a sandstone rock shelter that shows signs of human habitation and contains red pictograms with depictions of an anthropomorph and a zoomorph (bullock). More recently, the site has been associated with a nearby temple, and several statues have been erected in the rock shelter by devotees. These sites are described in detail elsewhere [69].

Figure 3. The rock art from Poeung Komnou in Siem Reap province, part of a series of newly discovered sites found in the Phnom Kulen area. Photo: Noel H. Tan.

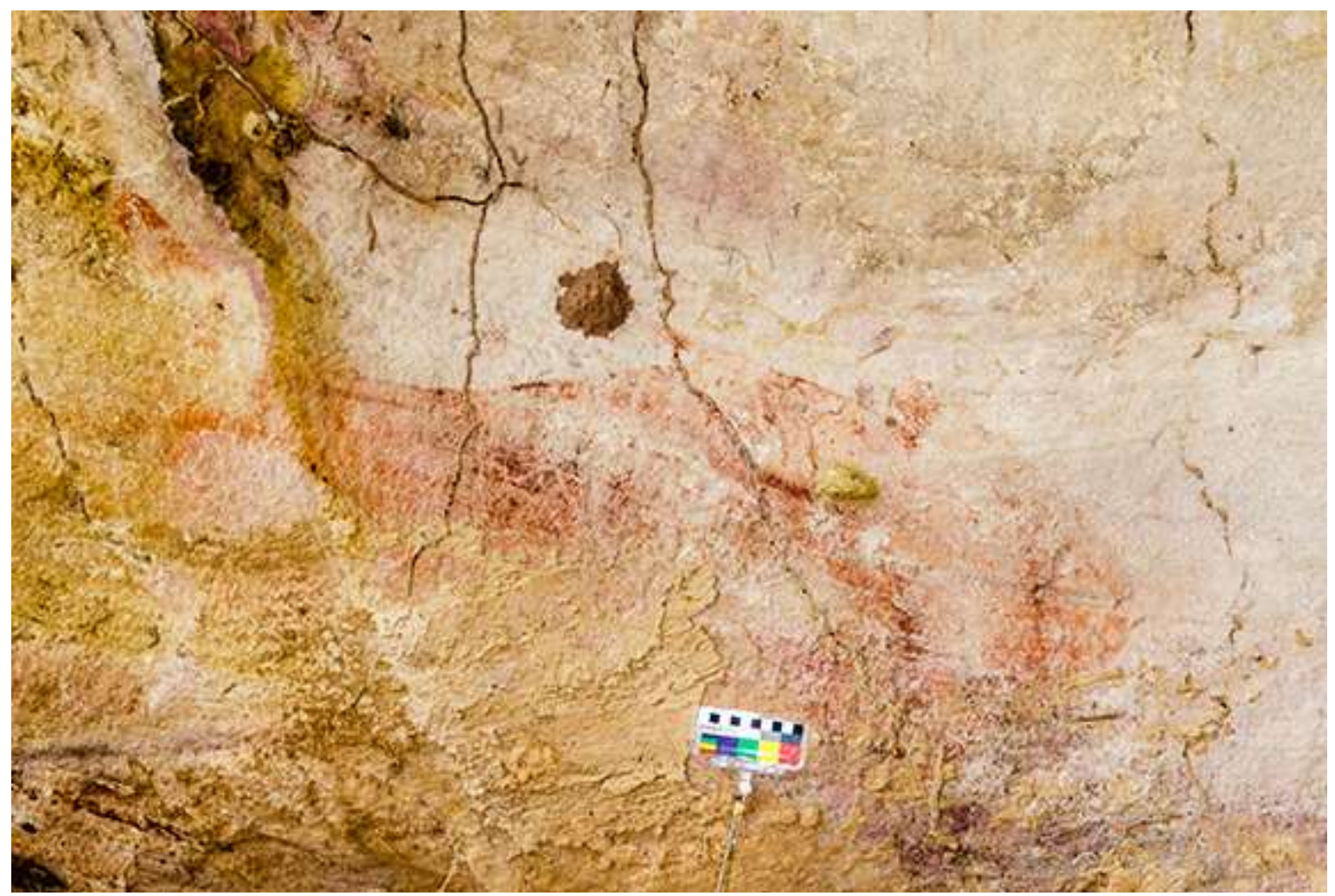




\subsection{Laos}

The archaeology of Laos is underdeveloped compared to its neighbours Thailand, Vietnam and Cambodia and as such there are no published reports about the rock art of Laos. Knowledge of rock art of this region has come primarily from Souliya Bouxaythip [70] from the Archaeological Research Division of the Ministry of Information and Culture, who presented an overview of the five known rock art sites in Laos at a workshop on rock art hosted by SEAMEO-SPAFA.

Tham Vang Sang (or Tham Wang Sang, in [28,70]) in Vientiane Province, some $60 \mathrm{~km}$ away from the capital Vientiane, is dated to the 13th century, containing bas-reliefs depicting the Buddha and therefore classed as a historic period rock art site. In Xayabouli Province west of Vientiane, an unnamed site contains petroglyphs of pecked anthropomorphic and zoomorphic figures, as well as several cupules. Another unnamed site is found in the northern Luang Namtha province; a red painting of an anthropomorph in spread-eagled position ([70], and also on display in the National Museum of Laos in Vientiane).

Luang Prabang Province contains at least three rock art sites which are located along the Ou River. The Pak Ou Caves are a popular tourist destination $20 \mathrm{~km}$ from the capital Luang Prabang, a pair of caves housing Buddhist shrines, but also containing a number of prehistoric and historic rock art [69-71] (Figure 4). Pha Nang Aen, also located in the vicinity of Pak Ou village, was mentioned by Srisuchat [28], as a painted cliff face located near the Pak Ou caves, although no information was provided about the subject of the panels. An additional site, Pha Taem ("The Painted Cliff") is located in the vicinity, near the village of Huoay Kuong, and contains red paintings and handprints along a cliff face overlooking the Ou River [70].

Figure 4. Rock art located on the cliff face outside the Pak Ou Caves in Luang Prabang Province. Photo: Noel H. Tan.

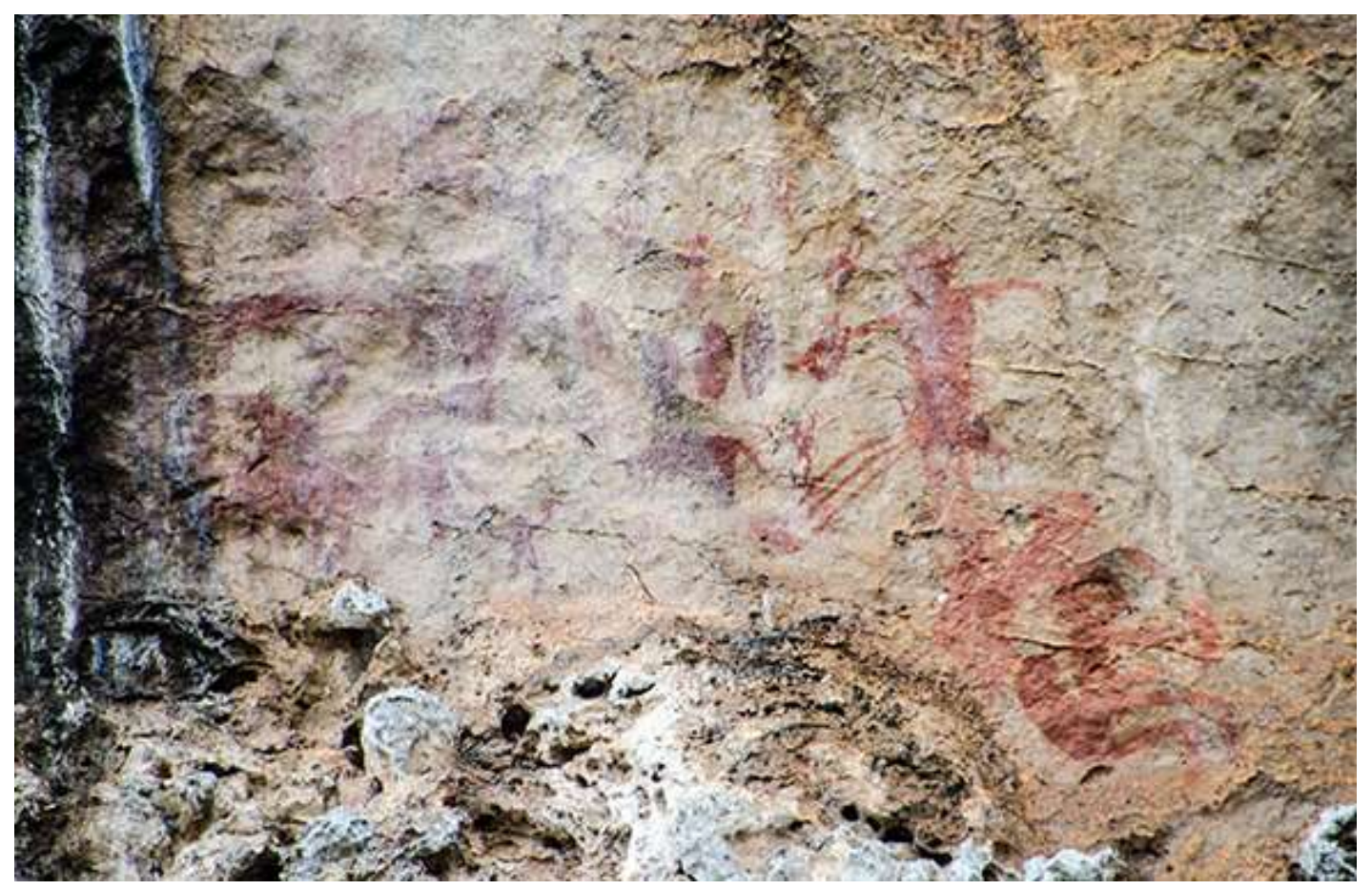


Laos is otherwise famous for the mysterious Plain of Jars in Xienkhuoang Province, a vast field of stone urns (and therefore classed as megaliths) first described by Colani in 1935 [72]. Some 90 sites of stone carved jars are strewn across the Xienkhuoang Plateau, although access is limited today due to the number of live munitions and unexploded ordnance left behind by American bombing runs in the early 1970s. They are dated to the Iron Age, between 500 BCE and 500 ACE, and are largely undecorated. The exception, a carved jar in site 1 of a human figure looks similar to a painting found in the Pak Ou Caves.

\subsection{Myanmar}

A handful of sites are known from the Republic of the Union of Myanmar (formerly known as Burma), but only two have been described in literature. The most prominent one is the Padalin (alternatively known as Pah-dah-lin, Badalin or Pyadalin) Caves which are found in Shan state. Comprising two sites the limestone rock shelter (Cave 1) and deep underground limestone cave (Cave 2) were first investigated in the late 1960s, with the excavations carried out in Cave 1. Dates of 11,000 to 13,000 years ago from near the bottom of the deposit were obtained by radiocarbon dating [13]. This site has a number of rock paintings of animals and stylised human hands with infilled designs on the main wall (Figure 5). U Aung Thaw ascribes a Neolithic date to the finds, although Moore [73] writes that the artefacts recovered more closely relate to the late Pleistocene. More recently, cupules were also discovered in Cave 1 of the Padalin caves and there were several faint traces of painted rock art at the entrance of Cave 2 [74].

Figure 5. A stylised human hand is one of the many paintings from Padalin Cave 1 in Shan State. Photo: Noel H. Tan.

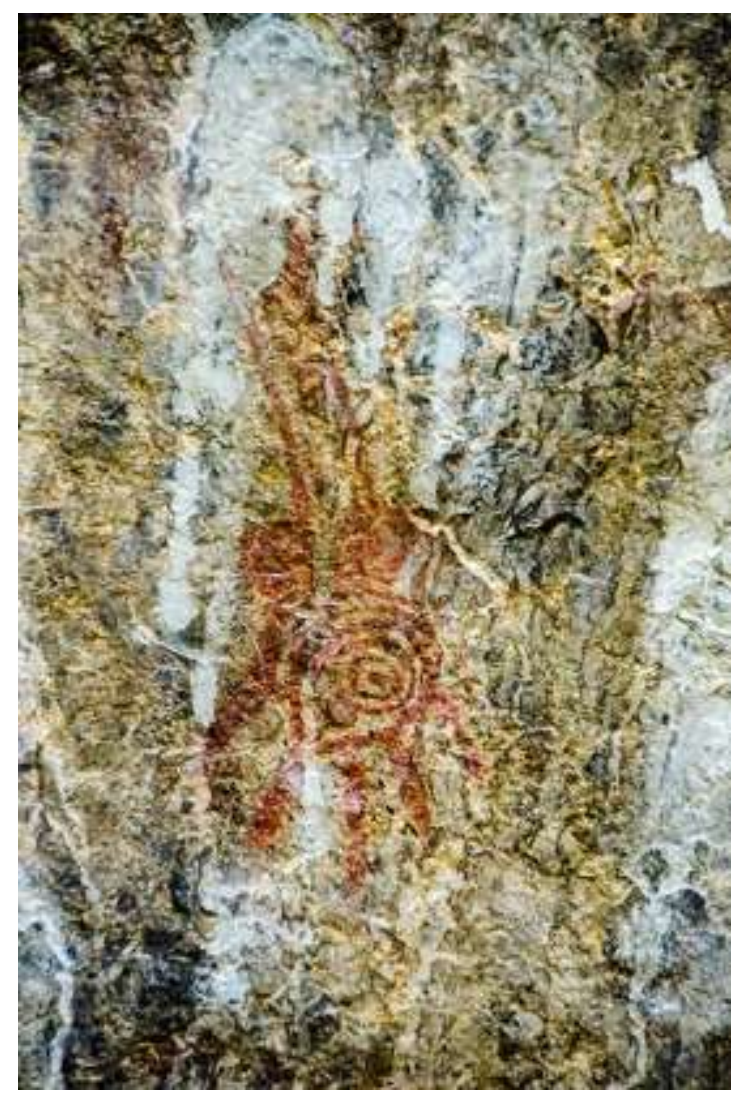


The other Myanmar site to be described in literature is the engravings at the Lemro Valley in Rakhine state. Gutman et al. [75] revisited two petroglyph sites that, according to their interpretation, were made during the post-medieval period of the 15-19th centuries. Their dating is based on similarities with artistic styles and attributes found in the nearby city of Mrauk-U.

Three other sites were mentioned by U Win Kyaing [76] during his country report to the SEAMEO-SPAFA Rock Art workshop in Bangkok. Citing a 1998 report by Hla Gyi Maung Maung to the local department of archaeology on the caves of southern Shan State, the Le-win Rockshelter contains a small set of red pictograms depicting anthropomorphs, some of them appearing to ride on "horses" or "bulls." Near the city of Myeik at Thaninthayi Division, the Yekan-au cliff paintings are another red pictogram site lacking other details. Finally, the Gyo Village in the Myingyan District of Mandalay Division were reported to have some 30 engraved boulders, three of which have been moved to the district council office. These three aforementioned sites appear to have been written about in local archaeological reports, but remain inaccessible to me at this stage.

\subsection{Peninsular Malaysia}

The rock art in Peninsular Malaysia consists mainly of rock paintings distributed throughout the central and northern states of the peninsula in the states of Perak, Kedah, Kelantan and Pahang. There are few detailed studies on any single rock art site in Peninsular Malaysia and reports are generally confined to broad overviews and descriptions [77-79].

Some rock art sites in Peninsular Malaysia are directly associated with the aboriginal population, known collectively as Orang Asli ("original peoples" in Malay). Evans [80] wrote the earliest account of such rock painting at Gua Kajang in the Lenggong valley of Perak. Evans [81] later described similar activity at Gua Badak in Perak, where he described the Lanoh Negritos creating parietal art portraying different aspects of tribal life. Williams-Hunt [82] observed the same activity 30 years later when the Lanoh Negritos drew a portrait of himself in his report; in another example, he featured a "recent drawing of a man leading a horse," illustrating the range of their decorative arts. Regrettably, Williams-Hunt did not expound further about the aboriginal practice of cave painting. Gua Badak is once again documented in 1988 by Faulstich [83], seeking to acquire pictures of the rock art which at the time were to be quarried for marble; fortunately the site has remained intact, and this author visited it in 2010. Faulstich noted that many of the designs on the walls of Gua Badak were similar to those carved on pieces of bamboo used by contemporary Negritos- "myth bamboos" that represented some kind of cultural knowledge [83,84]. Gua Kelilawar, another charcoal rock painting site in Perak, was reportedly gazetted as a historical site in 1988 by the local government, and contains depictions of anthropomorphs, zoomorphs and a depiction of a "boat carrying three men" [85].

Another ethnographically linked rock art site is Gua Luas in the state of Pahang, of which the art is said to be a panoramic representation of the surrounding regions [86]. Some panels of abstract art is said to represent everyday items used by Orang Asli, such as combs, blow pipes and decorative items. Gua Kechil, near the town of Raub, is also reported to contain black-coloured paintings attributed to the Orang Asli [87]. In Kedah, the site of Gua Batu Putih located near the town of Kodiang contains charcoal representations of a human anthropomorphs and zoomorphs [78,88]. The cave is located in the southern end of the limestone complex where the distinctive Kodiang tripod pottery was 
discovered; however, it remains to be seen if the two artefact types are related. In the eastern state of Kelantan, two pairs of charcoal rock art sites are known in the vicinity of Kuala Betis and Kuala Bering. At Kuala Betis, Gua Batu Cincin is a semicircular cave containing 53 figurines on 27 panels, the majority of which depict anthropomorphs in a "dancing posture with upraised arms" $[78,88]$.

Nearby, Gua Kambing contains representations of anthropomorphs, again depicted with upraised arms, along with abstract designs such as "spear-like" motifs and "inverted V-shaped" motifs [78]. The two sites at Kuala Bering, Gua Tagut and Gua Tampaq both contain representations of anthropomorphs and zoomorphs. In addition, the site of Gua Tagut is said to contain charcoal paintings similar to Gua Batu Cincin [78].

Only two rock art sites in Peninsular Malaysia use red pigment. Gua Cerita is a lesser-known attraction on the northern part of Langkawi Island, a popular tourist destination situated off the coast of Kedah. Local lore mentions the cave as the site of a legendary wedding between the royalty of China and Rome. The presence of Jawi writing has been dated to 1754, during the reign of Sultan Mohamed Jiwa II of Kedah [89]. Besides the red pictograms and writing, during recent visits to the site I have noted more recent rock art/vandalism of polychrome chalk drawings depicting cars, faces and houses.

Figure 6. A depiction of "mountain goats," part of the main panel of paintings at Gua Tambun, Perak. Gua Tambun is the largest rock art site in Peninsular Malaysia, containing over 600 motifs. Photo: Noel H. Tan.

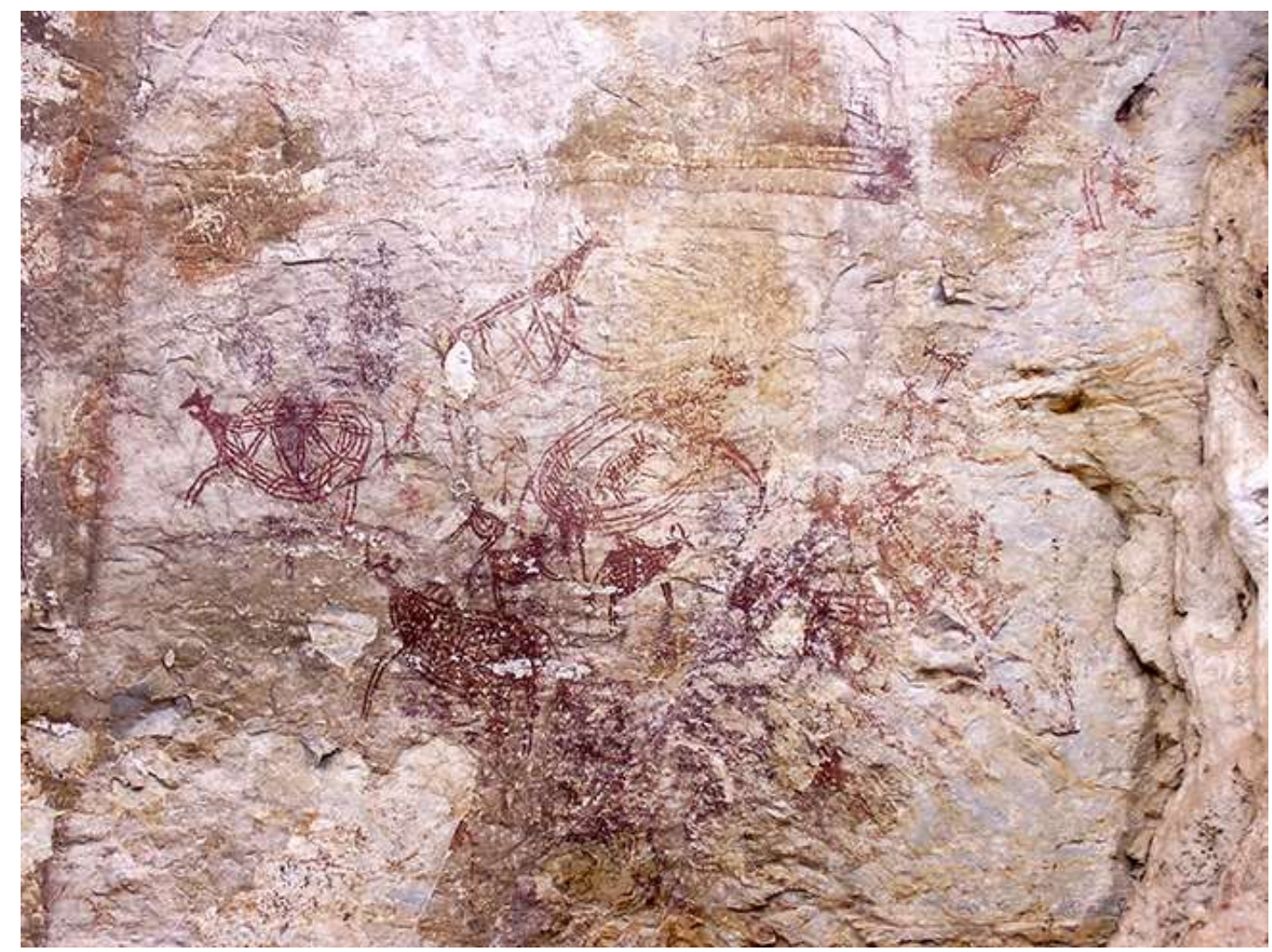

Gua Tambun is the better-known rock art site containing red-coloured prehistoric paintings. Situated just outside the city of Ipoh, the capital of Perak, Gua Tambun is a large rock shelter and cliff face that was first reported by Matthews in 1959 [10,11]. The site was re-investigated in 2008 for a Masters dissertation which was completed in 2010. The rock art consists predominantly of animal 
figures, anthropomorphs of varying shapes and poses, and repetitive abstract designs (Figure 6). The main panel of rock art was located six metres above the floor of the shelter, and contains over 500 paintings covering an area of approximately 27 square metres. The rest of the paintings were spread out in 10 other panels throughout the 100 metre-long shelter. Over 600 paintings were recorded from the limestone rock shelter, making Gua Tambun the largest and most complex rock art site in Peninsular Malaysia [90-92].

\subsection{Vietnam}

For various reasons it is difficult to ascertain the extent of documented rock art sites in Vietnam. The most famous site is the engraved rock field (Figure 7) at $\mathrm{Sa} \mathrm{Pa}$ in Lao Cai province, in northwestern Vietnam, and comprises a landscape with over a hundred engraved rocks [93]. The Sa Pa rock art was recently documented by a team from the Hanoi University of Art [94]. Depictions in the Sa Pa rock art site include abstract and geometric designs, weapons, anthropomorphs and writing. A similarly engraved boulder has been found in the neighbouring Ha Giang province by Trinh Nang Chung, in the district of Xin Man, which is inhabited by the Nung minority. The Xin Man petroglyphs are on a boulder measuring approximately 13 by $9 \mathrm{~m}$, containing 80 petroglyphs of mostly geometric and concentric circle forms [95].

Figure 7. One of the engraved boulders from the Sa Pa Engraved Rock Field in Lao Cai Province. Photo: Noel H. Tan.

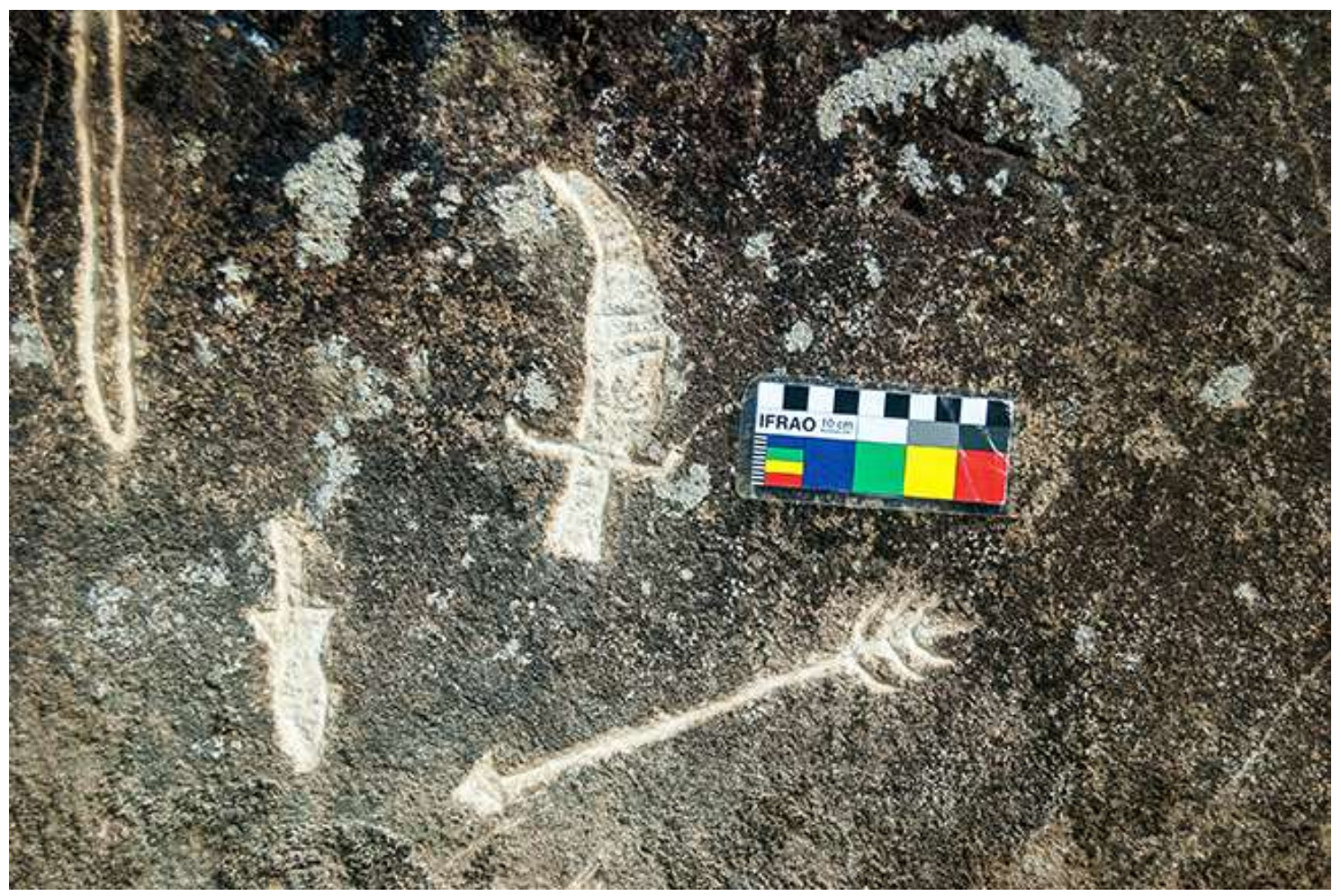

Reproductions of two more petroglyph sites are on display at the Vietnamese Museum of History in Hanoi: the Dong Noi Cave in Hoa Binh Province contains an engraving of a face, while the Thuong Pho Cave in Quang Binh Province contains thin incisions in the stone, one of which resembles a buffalo. No further information is available about these two sites. More recently, a team from the Institute of 
Archaeology and the Hanoi University of Culture, headed by Trinh, discovered a megalithic dolmen estimated to be 2,000 years old [96]. This find is located in Vĩnh Phúc Province of north Vietnam. Dolmens have also been reported from the Soc Son District of the greater Hanoi area [97]. Painted rock art was unknown in Vietnam until 2012, when a team led by Trinh discovered the Kho My Cave in Ha Giang Province in 2009 [98,99]. The cave is located in the Tung Van Commune of the Quan Ba District and depicts anthropomorphs, some of which are sporting "horns."

\subsection{Singapore}

The archaeology of this tiny island nation befits its size, and it is unsurprising that there are no painted rock art sites in Singapore. However, when Bland [1] described a wedge-shaped stone standing at the mouth of the Singapore River, we find in Singapore the likely first mention of a rock art site in Southeast Asia. The Singapore Stone, as it has come to be known, was a sandstone boulder approximately 10 feet high, 5 feet wide and 9 feet long that contained Indic inscriptions that remain undeciphered today; they are thought to be Sanskrit or Old Javanese [100,101]. Sadly, what may possibly have been the country's only rock art site was destroyed by the English colonisers in 1843, when the boulder was dynamited as part of construction work to widen the river mouth [102]. A fragment of the stone inscription lies on display at the National Museum of Singapore and has since been designated as a national treasure (Figure 8).

Figure 8. The Singapore Stone once stood at the mouth of the Singapore River and a fragment now sits on display at the National Museum of Singapore. Photo: Noel H. Tan.

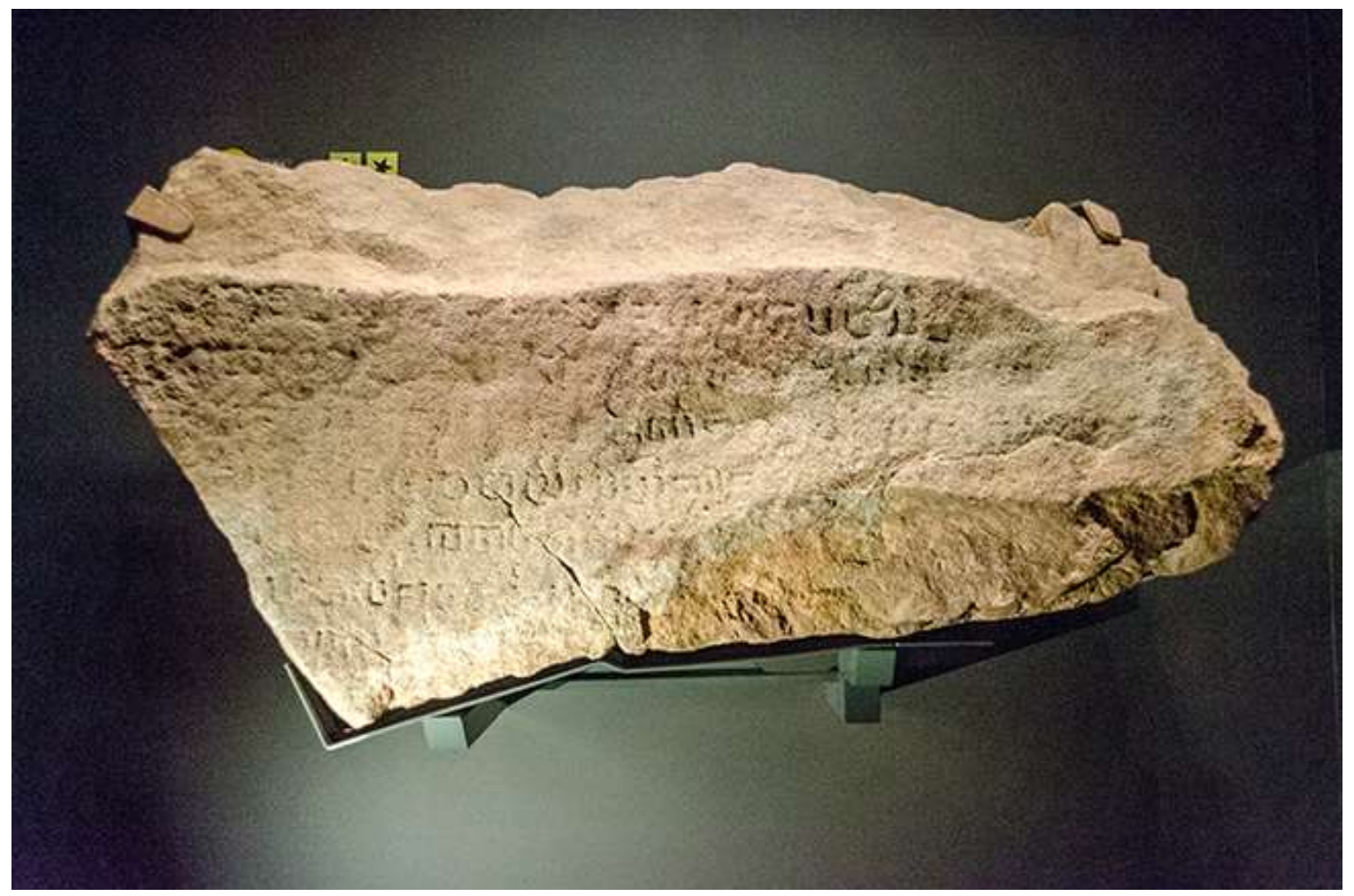




\section{Island Southeast Asia}

The waters that form the Indian Ocean, the Straits of Malacca and the South China Sea separate Mainland Southeast Asia from Island Southeast Asia. This region discussed here comprises Indonesia, East Malaysia, East Timor, the Philippines and Brunei, the last of which has no known rock art sites. The main languages from these countries come from the Austronesian language family, which is thought to originate from Taiwan and South China [103]. In addition to numerous rock painting sites found throughout this region, there is a fairly large corpus of megaliths, the production and use of some still continue to the present day.

\subsection{Indonesia}

Most of the rock art known from Island Southeast Asia is found in Indonesia, an archipelago of over 18,000 islands. According to Kosasih [104], rock painting in Indonesia dates back to the epi-palaeolithic period and continues through the Neolithic and even in some early metal-using cultures. Moving along the map from west to east, the rock art of Sumatra, Java, Borneo, Sulawesi, the Lesser Sundas and West Papua are discussed in turn.

Rock art in Sumatra comes primarily in the form of megaliths. One of the most famous megalithic sites is found in Pasemah, in southern Sumatra which contains over 60 megaliths, and has been associated with the early first millennium CE because of the depiction of bronze Dongson-type drums [105]. The two most notable depictions is the Batugajah, which depicts a rider on an elephant holding a bronze drum [105], and the bronze drum depiction at Batu Tatahan Air Puar [106]. In the same area, Caldwell [107] described the new discovery of a painted cist-grave. Other megalithic statue sites such as Baturedja, Lesungbatu, Muara Komering and Pagerdewa have been mentioned by van Heekeren [9], while two megalithic complexes are also known from the Nias Islands and Samosir Island [108]. Recent finds include megalithic sites at the Segayun and Skendal villages [109,110]. A 10th century inscription in the Nagari script is also found on Karimun Besar, an island some $30 \mathrm{~km}$ west of Singapore in the middle of the Straits of Malacca. Its existence has been known since 1873, and its translation and context was last discussed by Caldwell and Hazlewood [111] (Figure 9). More recent work has been conducted by Bonatz et al. [112], whose work in Jambi Province has uncovered some 20 megaliths, often carved with decorative motifs. Most significantly, Simanjuntak [113] reported the first discovery of painted rock art in Sumatra, at the site of Gua Harimau. The paintings are red in colour which suggests a prehistoric dating, and the site itself is associated with the Neolithic. Research on this site is still ongoing (Figure 10).

Painted rock art has yet to be found on the island of Java, and like the neighbouring Sumatra, rock art comes mainly in the form of megaliths - stone cist graves and dolmens - much of which have been noted during the late-19th and early-20th centuries by Dutch scholars [8,9,114-117]. In 2001, a petroglyph site was discovered in West Java on Sangkur Mountain. Parts of the engraved panel extend to below the surface, and have the potential to be dated with careful excavation [118]. 
Figure 9. The Karimun Inscription on Karimun Besar Island in Riau Islands Province. Photo: Noel H. Tan.

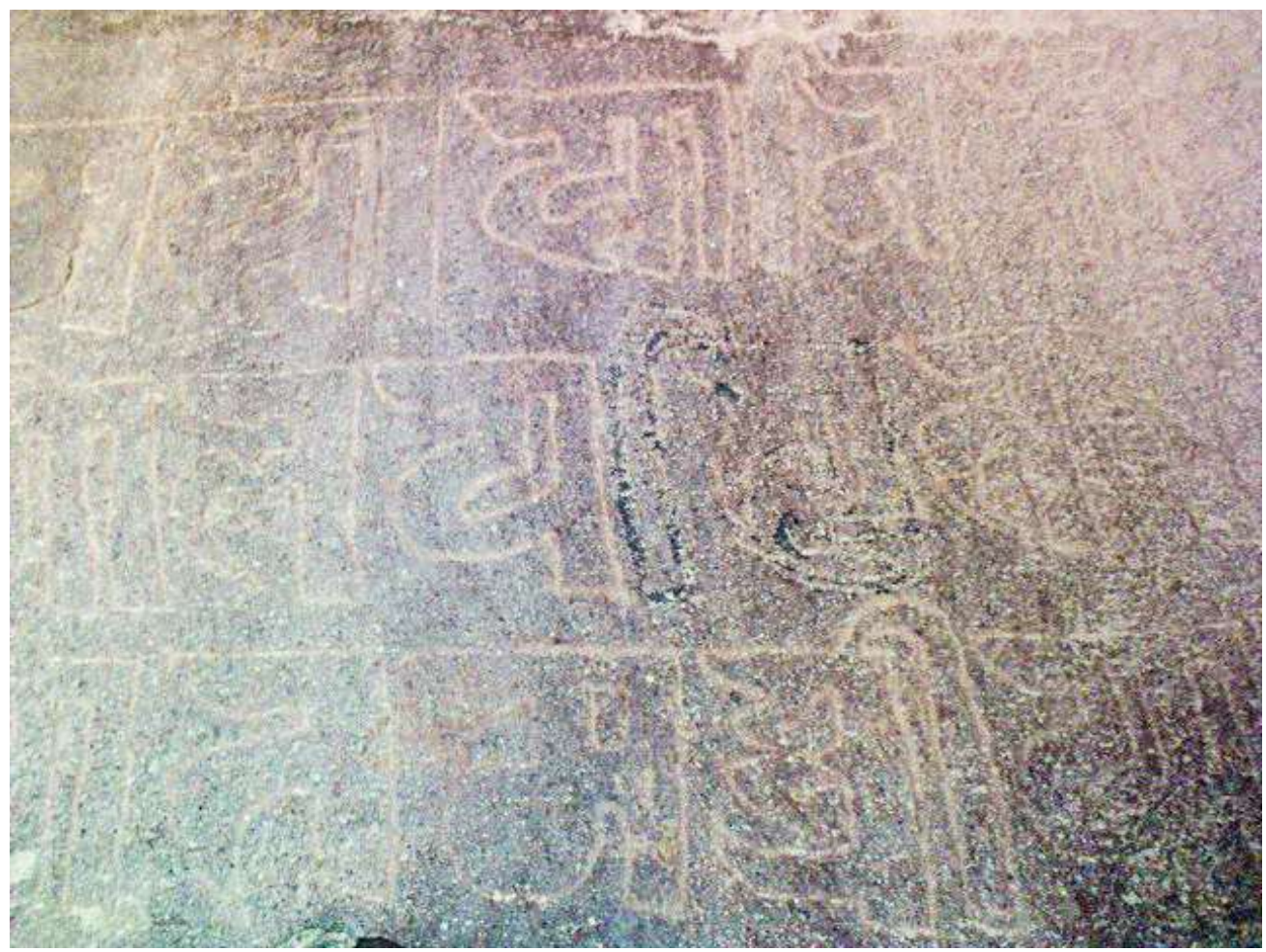

Figure 10. The recently discovered rock art of Gua Harimau in southern Sumatra is the first instance of painted art found in Sumatra and overturns a long-held notion that such rock art did not exist on the island. Photo: Truman Simanjuntak.

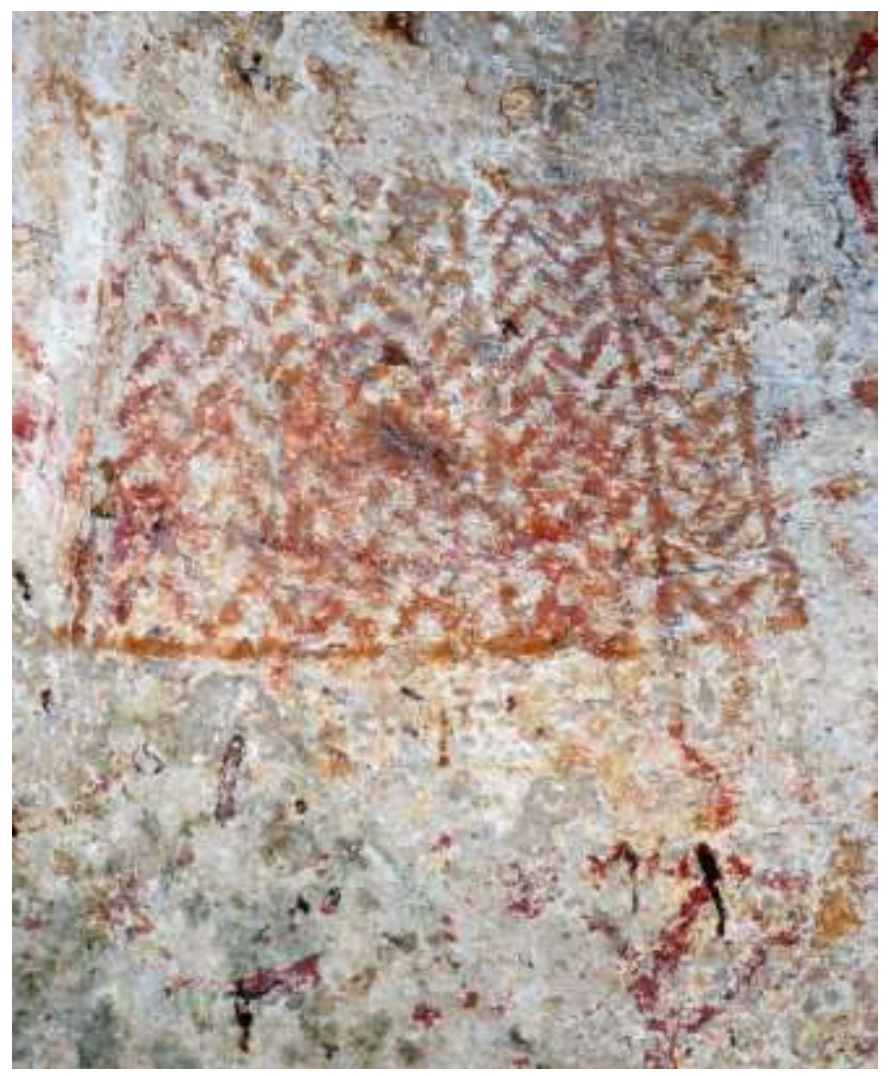


In Borneo, which is split between East Malaysia (see later section) and Indonesian Kalimantan, we have one of the early references to rock art in Southeast Asia from Grabowsky [3], who reported the charcoal "scribbling of natives" from Liang Lumba at Mount Mandella. Megalithic structures in the form of dolmens (Apo Kajan), rock graves (Long Pura) and sarcophagi (Long Danum) have also been noted by van Heekeren [9], while a single rock engraving site of Long Po was noted by Kusch [4]. More recent research has been conducted by Jean-Michel Chazine between 2000 and 2009, on a series of caves in East Kalimantan featuring painted hands and hand stencils (see [119-125]). The rock art from Gua Saleh in particular has been dated using uranium-series and AMS radiocarbon to produce a remarkably old minimum age of 9,900 years [125].

Our earliest knowledge of painted rock art from Sulawesi comes from van Heekeren [8], who wrote about the "leaping babi-rusa" (a jungle boar) from Leang Pattae, and other red painting sites of Leang Burung and Leang Djiarie. At least fifteen additional sites have since been identified from local archaeological efforts; such as Garanggung Cave, Salluka Cave and Cumi Lantang, which are to be found in southern Sulawesi and contain hand stencils and other zoomorphic figures [104]. While most work has been done in areas of easy access such as Maros and Muna Island, the recent find of hand stencils and the depiction of an anoa in Gua Batti in the Bone region suggest the potential for many more rock art sites to be found [126]. In addition to the painted sites, two engraving sites, Tinco and Lawo, are known from southern Sulawesi depicting geometric linear patterns and a horned deer [127]. Kosasih also conducted surveys of painted sites in Muna Island on the southeast coast of Sulawesi and reported at least ten sites from there [104]. Megaliths generally come in three forms: stone vats and stone statues [9], and menhirs - the last of which are found primarily in southern Sulawesi [128].

The Lesser Sundas is the collective name for the smaller islands found south of Sulawesi and east of Java; the rock art in this area is varied. From as early as 1884 , rock art has been reported from the Kai (or Kei) Islands [2] and later surveys by van Heekeren [8] report that the rock paintings there are predominantly red in colour. One Kei Island site in particular, Dudumahan, was described in detail by Ballard [129]. Rock paintings were discovered by Röder at the Seleman Bay of Seram Island situated between Sulawesi and West Papua [8,130], which depict anthropomorphs, hand stencils and "lizards" in red, while boats and birds are depicted in white. Latinis and Stark [131] mention rock art sites on Seram Island, but it is uncertain if the Sawai sites are new or the same ones noted by Röder and van Heekeren. On the island of Bali, van Heekeren [9] has noted the presence of at least eight stone sarcophagi sites, and stone sarcophagi continue to be found today [132,133]. Two sites are known from Flores, a petroglyph site depicting a bronze dagger possibly related to the Dong Son culture and thus related to the bronze age petroglyphs at Pasemah in Sumatra [104,134]; while Kusch [4], citing an unpublished report, noted the presence of black paintings on Mbikong Cliff.

West Papua, formerly known as Irian Jaya, is the easternmost province of Indonesia. Rock paintings there were first reported by Röder [130,135] and then by the National Research Centre of Archaeology in 1975 and 1976 [104,136]. Sites have been located in the limestone cliffs of the Maccluer Gulf and on several islands, including Ogar and Arguni. Kosasih [104] noted that some of the paintings were referred to by the local people as amber-sibui, or "written by aliens" and that some of the motifs share similarities with those of the Kei Islands. These rock art discoveries of West Papua were synthesised in a volume by Arifin and Delanghe in 2004. Most recent work in West Papua has been conducted by Chazine on the red paintings and hand stencils of the Misool Archipelago [137-139]. 


\subsection{East Malaysia (Borneo)}

Besides Indonesian Kalimantan, the island of Borneo is shared with the Malaysian states of Sabah and Sarawak (collectively known as East Malaysia) and the Sultanate of Brunei. In East Malaysia, the Niah Caves complex of Sarawak is one of the best-known archaeological cave and rock art sites in Southeast Asia. Situated on the northern side of Borneo, the cave was discovered and worked on by Tom and Barbara Harrisson from 1954-1962, and was also recently investigated by another team of archaeologists from the University of Cambridge to confirm Harrisson's earlier findings. Red paintings, described as haematite, were discovered in 1958, with some positioned up to 15 feet above the cave floor and extending over an area 200 feet wide [12]. The paintings depict anthropomorphs standing on what appear to be boats or ships (Figure 11). The pictogram chamber, Gua Kain Hitam, is associated with funerary burials in boat-like coffins. Harrisson associates the rock art with the "ship of the dead" motif and points out stylistic similarities with the boats portrayed on Dong Son drums; similar ship motifs are found in the Manunggul jar of the Philippines and the Racolo rock art in East Timor [12]. The association of the boat burials with the ship paintings put the paintings to be between 1,000 to 2,000 years old [140]. Chemical analysis of the pigment in Niah demonstrated that it is not made of haematite as originally thought, but derived from the resin of a local tree. Other painting sites from Sarawak include the charcoal drawings at Gua Sireh [140], and the Bukit Sarang Caves of Lobang Ringen and Lobang Batu Putih [141-143]. Two sites are known from Sabah: Gua Hagop Bilo contains depictions of men in ships [77,144,145] and the Madai Caves in Sarawak contains charcoal drawings overlain with a white bird [144].

Figure 11. The "ships of the dead" of Gua Kain Hitam in Sarawak are associated with boat-shaped coffins found in the same cave. Photo: Nicholas Gani.

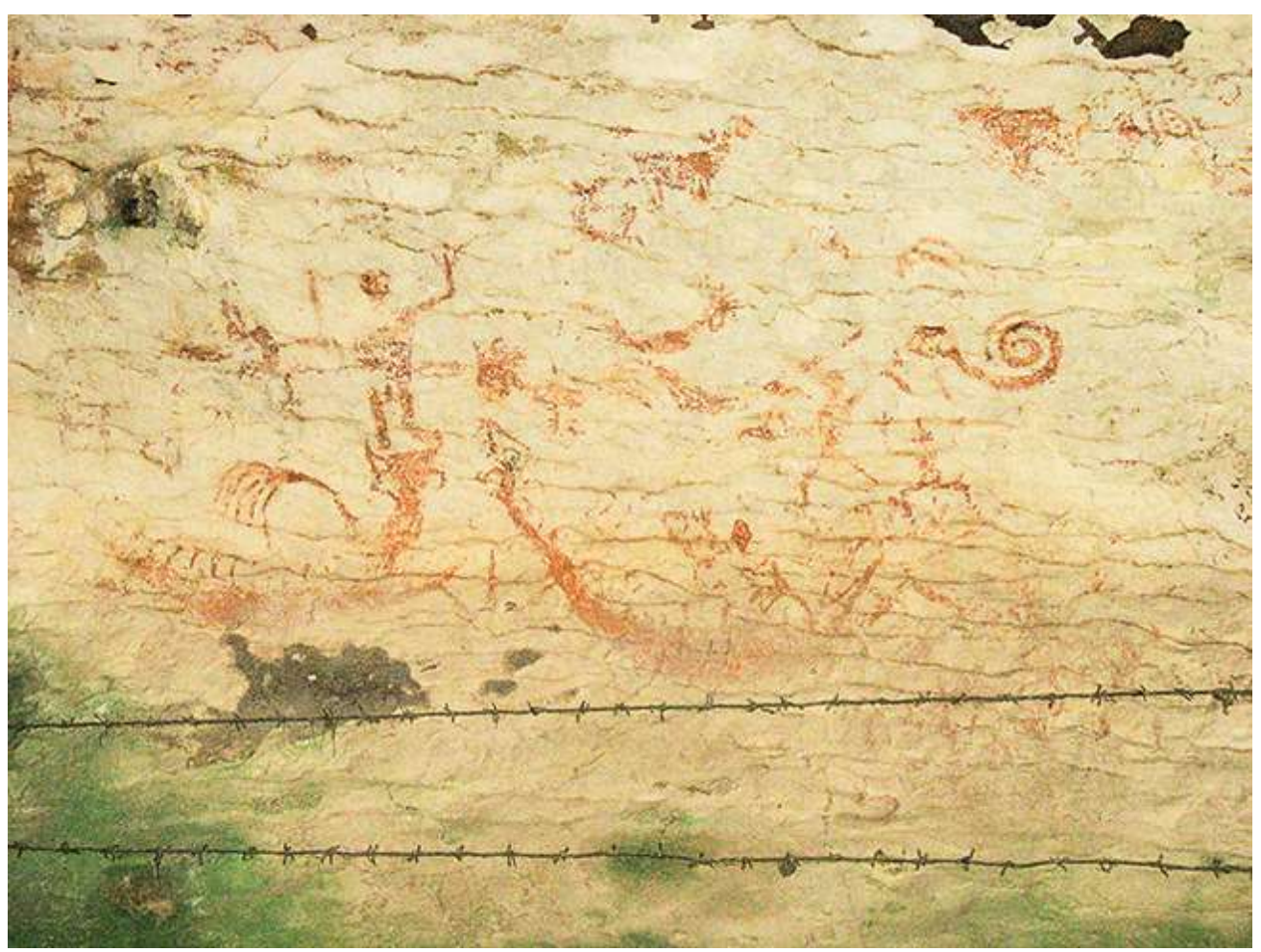


Circular rock engravings were found on a boulder near the Lumuyun River in Sabah by Harrisson $[147,148]$ which appear disassociated with the Tagal people living there during the time of the discovery. Kusch [4] also reported on the work of Baier, who recorded three Sarawakian engraving sites in the late 1970s: Batu Pilipus, Bulongan and Pa Upan. New engravings were discovered in Kuching in 2010 by Taçon and Sherman adding 11 sites to those noted by Harrisson and O'Connor Jr. previously [149,150]. Like much of Indonesia, megaliths are far more common; Harrisson's survey of megaliths identifies some 485 sites in Sarawak and 165 sites in Sabah [148,151]. Phelan noted 133 megaliths in his survey of the megaliths around Kota Kinabalu in Sabah and it is unsure if this number overlaps with Harrisson's, although the megaliths in Phelan's survey have all since been destroyed as a result of development [152]. Other recent research efforts to more fully document some of these sites include the work of Ipoi Datan of the Sarawak Museum on crocodile-shaped mounds [153], by Lloyd-Smith and Datan [154] on the megaliths of the Kelabit highlands and by Azlin et al. and Ratnah et al. on a complex of 34 megaliths in Penampang [155,156].

Figure 12. The stone faces of Lene Hara cave in East Timor, a cave also known for painted rock art. Photo: Sue O’Connor.

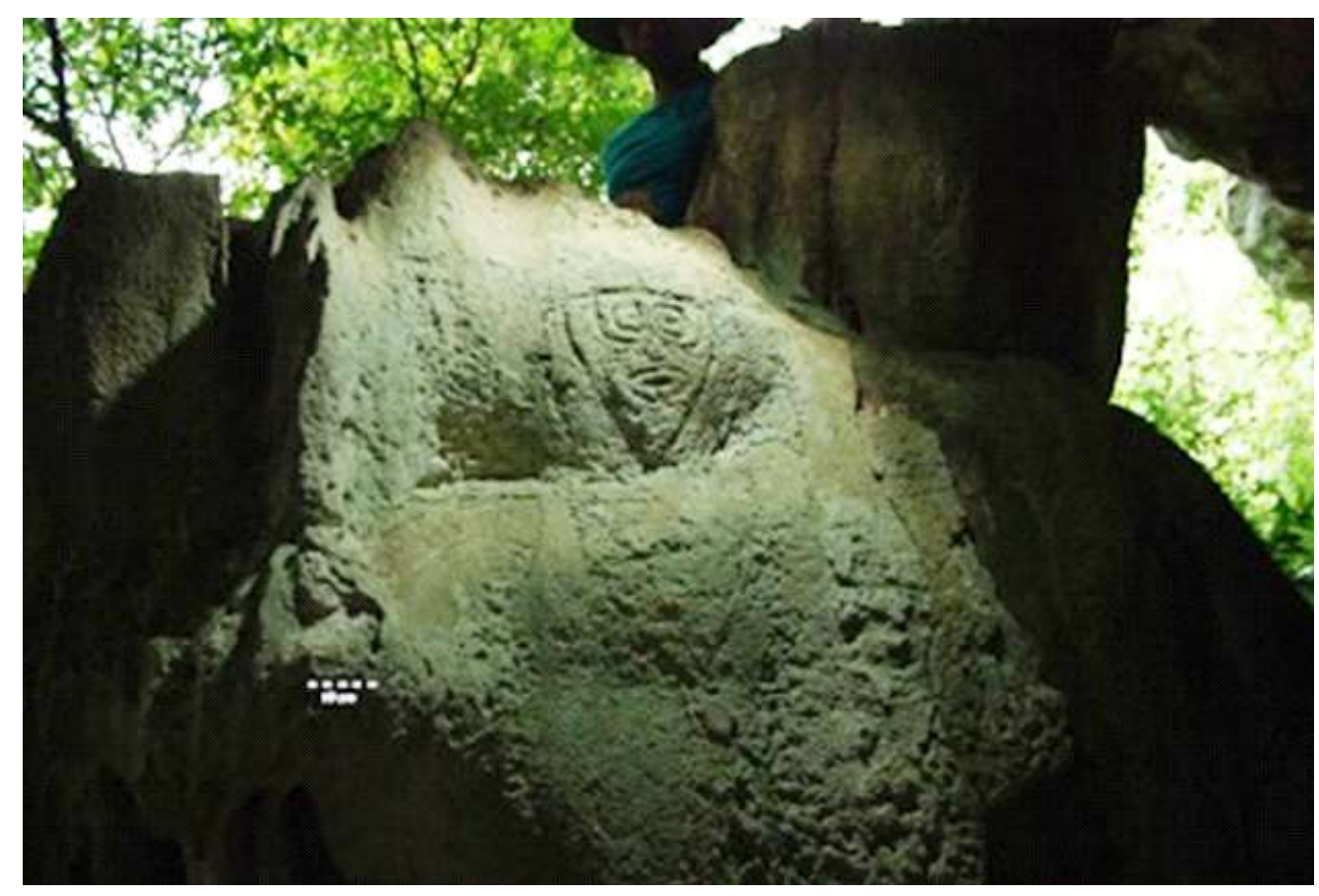

\subsection{East Timor}

Nestled in the middle of the Indonesian islands, it is not surprising that we find many rock painting sites in East Timor, and the sites are concentrated on the northern and northeastern side of the island. Six sites were discovered by de Almeida [157] and Glover [158] and additional ones have been discovered in the last decade $[159,163,164]$. In inter-site and inter-regional contexts, the rock art depicts several distinct motifs such as the flying fox, anthropomorphs, geometric designs and boats, which show strong affinities to rock art further east in the Maccluer Gulf and the Kei islands in Indonesia. Some of the boats and common sun motifs also share affinity with the Dong Son art depicted on the ubiquitous bronze drums found throughout Southeast Asia [159-161]. Attempts to date 
Lene Hara pigment from exfoliated rock fragments using uranium-series dating indicated multiple phases of painting with pigments dated to younger than 6,300 years BP, and a possibly older paint layer between 24,000 and 29,300 years ago [162]. Lene Hara produced yet another surprising find in 2010: two groups of petroglyph faces that were hitherto undiscovered were dated by uranium-series as between 12,500 and 10,200 years old [163] (Figure 12).

In other recent work in the Manatuto region of East Timor, rock art was discovered at the site of Hatu Wakik (Hawak) in the form of negative hand stencils and abstract geometric shapes. Lithics excavated from the site were dated to between 3,000 and 5,000 BP [164].

Figure 13. The Angono Petroglyphs in Rizal province is one of the best-known sites in the Philippines. Photo: Grace Barretto-Tesoro.

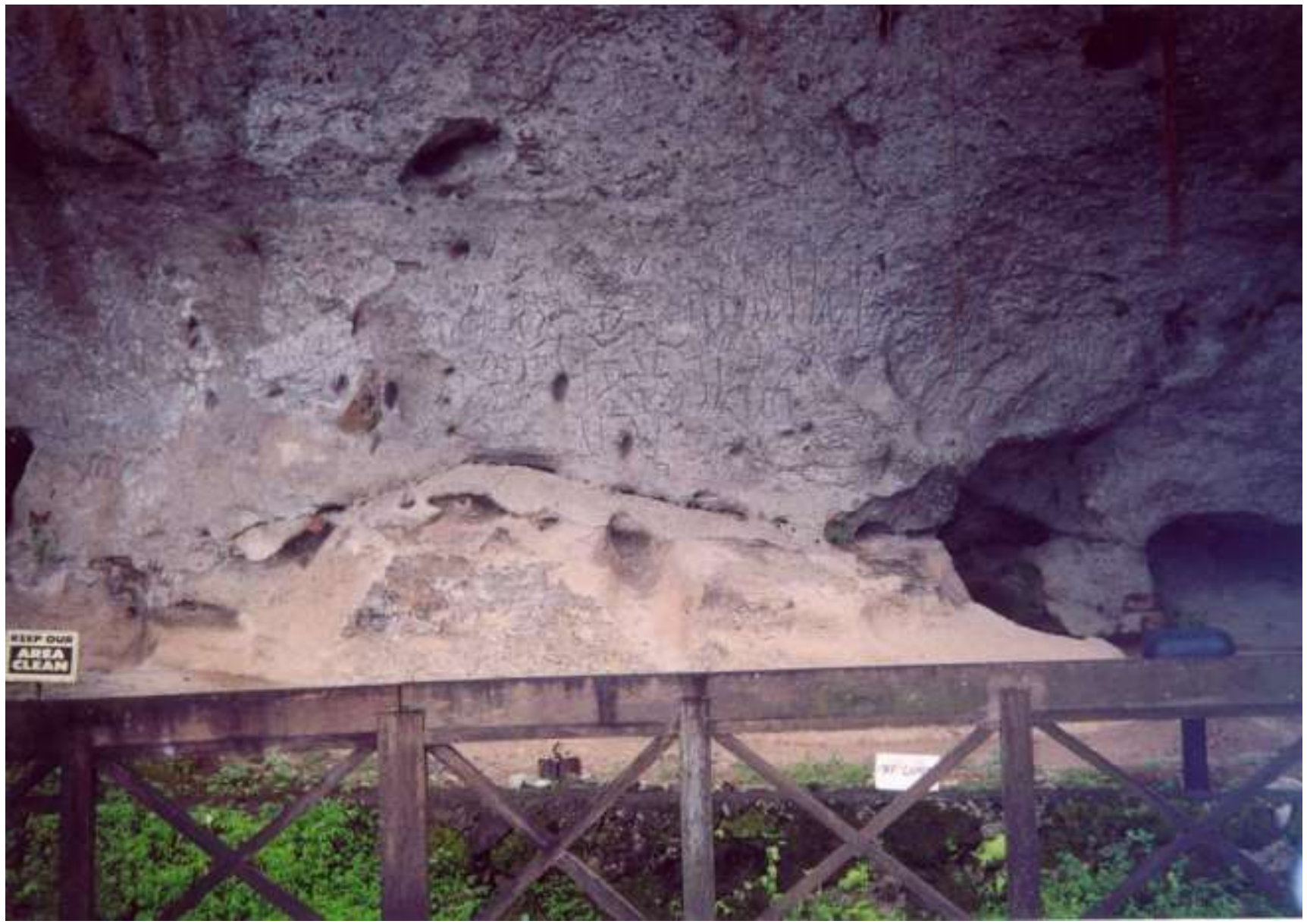

\subsection{Philippines}

Not many sites are known from the Philippine Islands; the most prominent is the Angono Petroglyphs in Rizal Province in the island of Luzon containing some 127 anthropomorphic figures, ascribed to the late Neolithic period approximately 3,000 years ago (Figure 13). Barretto-Tesoro [165] reviewed the research on the Angono petroglyphs and highlighted the lack of knowledge about the petroglyphs despite there having been two excavation programs since their discovery in 1965. Peralta [166] has previously remarked that the petroglyphs are similar to those made by the Tau't Batu, an indigenous cave-dwelling tribe in Palawan. The Tau't Batu pictograms (erroneously described as 
petroglyphs) in Ugpay Cave have a long-standing tradition that goes right up to the ethnographic present, although the people themselves do not find the activity particularly significant.

Another petroglyph site exists near Alab, in Mountain province, but is dated not earlier than 1,500 BCE. Like Malaysia, Philippines is home to two kinds of pictogram sites; black charcoal paintings have been found in Penablanca in Cagayan province and Singapan Caves in Palawan: while red paintings have been discovered in the Anda Peninsula of the Bohol province $[167,168]$.

\section{General Observations}

On the mainland, Thailand has the greatest number of reported sites due to its relative stability and openness, which has allowed archaeological research and led to the documentation and publication of a number of sites. In contrast, the neighbouring countries of Myanmar, Laos and Cambodia have only a handful of sites known-some of them recently discovered, while many whose existence have not been communicated to the larger academic or public community. Similarly with Island Southeast Asia, most of the rock art known from this region is concentrated within Indonesia, particularly in the eastern Indonesian islands. East Timor and the Malaysian states of Sabah and Sarawak are equally dense in rock art site distribution while little is known about rock art from Java and the Philippines. From this large corpus of sites we can make some generalisations about the rock art of Southeast Asia. Pictogram sites are by far the most widespread type of rock art found in Southeast Asia, and megaliths, while more numerous, tend to be limited to specific regions. Petroglyph sites are uncommon, but still found distributed throughout the region.

Like most rock art elsewhere in the world, the dating of such sites remains a problem. There have been few attempts to directly date the rock art of Southeast Asia, but where we have dates suggests that the rock art may be surprisingly old: direct dating of Lene Hara paintings in East Timor by uranium-series dating put the age of the rock art at a minimum of 6,300 years, and possibly as old as 26,000 years [162], whereas the petroglyphs range between 10,000-12,000 years [163]; comparisons of dates derived using radiocarbon and uranium-series dating at Gua Saleh in Kalimantan indicate antiquity of at least 9,900 years [125]. It is interesting to note that we currently only have direct dates derived from Island Southeast Asia than Mainland Southeast Asia, but their considerable antiquity suggests that some rock art of the mainland would be of equal age or older.

Some sites can be dated using iconographic identification, epigraphical and art historical methods, which put them into the historical period and the more recent past. In some Cambodian examples such as Poeung Komnou, we are fortunate to have inscriptions that date at least some of the rock art at present [67]. The depiction of cars and bicycles on the walls of Gua Badak [82] and European-styled masted ships and Chinese junks in Tham Viking [20,56-58] give an indication of the relatively recent date of these paintings. Thailand, in particular, has classed an entire group of rock art sites as belonging to the historical period [26].

Most often, rock art sites are dated in association with the excavated finds in situ, or found in the same area. Radiocarbon dating of sediments in Myanmar's Padahlin Cave produced dates of 7,000 and 13,000 years old in association with red-stained stone tools [73]. Matthews described the artefacts recovered from his excavation at Gua Tambun to exhibit a "Hoabinhian" character [11], although the date has since been revised to the Neolithic period due to the find of a cord-impressed pottery sherd 
$[77,169]$. The painted rockshelter of Ban Rai in northern Thailand contains two occupation periods, the late Holocene and early Holocene/Late Pleistocene, and a stained limestone "cup," possibly a palette, was recovered from excavations. That they are often found in caves and rock shelters throughout Southeast Asia further lends support to a "prehistoric"-presumably hunter-gatherer-provenance.

As noted from Malaysian examples discussed earlier, we do know of contemporary groups who still live hunter-gatherer lifestyles, some of which have been reported to have created rock art in the last century. What sets the modern rock art apart from older examples is primarily colour-red pictograms are thought to be older than black ones. Where both occur, black pictograms usually superimpose red paintings, but not the other way around. The black paintings often appear to be superimposed over red motifs, depict modern subjects and have ethnographic accounts related to them, such as those at Gua Badak in Malaysia [83,170]. Polychromatic paintings are also associated with more recent or historical period painting activity [55,56]. From these few lines of evidence available from the region, the general idea that emerges is that rock art sites containing red rock paintings without any diagnostic iconography (which is often) tend to be attributed to the prehistoric period.

Some patterns can also be detected on a regional scale. Ballard has posited the existence of an Austronesian Painting Tradition located throughout the eastern Indonesian islands and the Western Pacific, which is characterised by red rock art located at high locations in association with the sea [171]. Hand prints and negative hand stencils also frequently occur in sites on the eastern Indonesian islands, particularly in Sulawesi, Kei Islands, Borneo and East Timor. Megaliths, which are uncommon in Mainland Southeast Asia, are found throughout the Indonesian islands, famously in Sumba and as far west as the island of Nias, off Sumatra, to Irian Jaya in the east. This distribution does not seem to extend north to the Philippines, but it has crossed the Straits of Malacca to the states of Malacca and Negri Sembilan, where many of the ethnic Malay population identify their origin with the Minangkabau people of Sumatra [172]. Another distinct distribution of rock art can be found in the northeast areas of Southeast Asia, where a traditional of carved boulders can be found in northern Vietnam, Hong Kong and Taiwan [173]. What is also significant is the places where rock art (rock paintings in particular) has yet to be found-the central and southern sections of Vietnam, the Philippines and Java. Sumatra was thought to be devoid of painted art, but the recent discovery of Gua Harimau [113] has overturned that notion and suggests that many more such sites remain to be found.

This survey demonstrates that contrary to prevailing thought, there is a significant amount of rock art in the region (Figure 14). We now know that rock art, as a marking in the landscape in one form or another, exists throughout Southeast Asia - and is found in almost every modern nation-state. By my count from the existing literature, there are at least 600 known pictogram and petroglyph sites in Southeast Asia, and when megalithic sites are considered, the number reaches approximately 1,500.

Rock art research in Southeast Asia has certainly intensified in the last decade, and the potential for further research is immense. At the time of concluding this paper, the 20th Indo-Pacific Prehistory Association Congress was held in Siem Reap, Cambodia and the proceedings included three panels focusing on rock art and megaliths. Many new Southeast Asian sites were announced but could not be included in this paper in time. There is presently much potential for the study of rock art in Southeast Asia, and what it can tell us about the human past. 
Figure 14. Location of main rock art sites mentioned in text. Points can refer to individual sites or cluster of sites. Southeast Asia contains many other sites have not been indicated in this map. Map: CartoGIS unit, ANU College of Asia and the Pacific, The Australian National University.

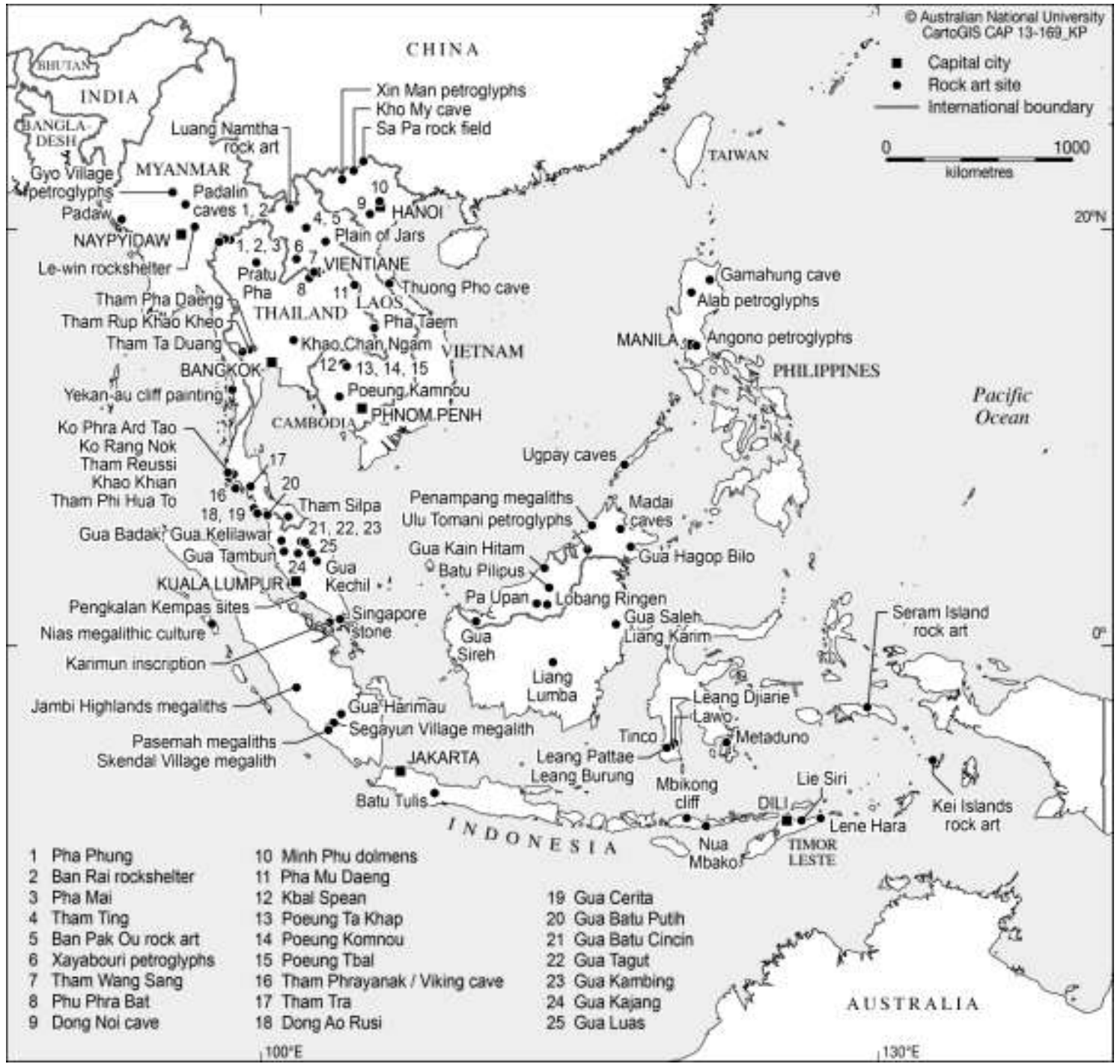

\section{Acknowledgments}

Many thanks to Sue O'Connor and Paul Taçon and the reviewers for their invaluable comments on the paper and to Kay Dancey and Karina Pelling of the CartoGIS team from the ANU College of Asia and the Pacific. I would also like to acknowledge the collaboration of the Department of Archaeology and Natural History from the ANU College of Asia and the Pacific, the Apsara Authority (Cambodia), the National Research Council of Thailand, the Fine Arts Department (Thailand), the Ministry of Information, Culture and Tourism (Laos), the Department of Archaeology, National Museum and Library of the Ministry of Culture (Myamar), the Robert Christie Centre of the University of Sydney and the Archaeology Unit of the Nalanda-Srwiwjaya Centre at the Institute of Southeast Asian Studies in Singapore in facilitating my rock art research in recent years. Also, a personal shout-out to friends and colleagues Grace Barretto-Tesoro, David Brotherson, Jutinach Bowonsachoti, Gemma Boyle, Stephen Chia, Geoff Clarke, Brian Egloff, Nicholas Gani, Foo Shu Tieng, Hen Chenda, Heng 
Sophady, Heng Than, U Hla Shwe, Im Sokrithy, Kasper Hanus, Khieu Chan, Lindsay Lloyd-Smith, Thonglith Luangkhot, U Man Thit Nien, Mokhtar Saidin, Amphone Monephachan, Muong Chan Raksmey, U Myo Min Kyaw, Liz Price, Natalie Ong, Dougald O’Reilly, Sakada Sakhoeun, Rasmi Shoocongdej, Truman Simanjuntak, Duangpond Singhaseni, Atthasit Sukkham, Sulatt Win, Watinee Tanompolkrang, Mai Lin Tjoa-Bonatz, Udom Rangsey, Veronica Walker-Vadillo, Charmaine Wong and Christine Yong for their invaluable help in various research projects.

\section{Conflicts of Interest}

The author declares no conflict of interest.

\section{References and Notes}

A note on names: As a region that befits its diversity, naming conventions in Southeast Asia vary from country to country, and sometimes vary within countries. Vietnamese, Chinese and Cambodian names have their family names listed first and are referenced by their family names. Burmese/Myanmar and Indonesian names do not follow a first name, last name system; and Burmese names are sometimes prefixed with a monosyllabic honorific (commonly in this study, ' $U$ ' which means Uncle or Mister). Names are thus written and referenced in full. Malaysia is a multi-ethnic society, the two main ethnic groups being the Malays and the Chinese. Chinese names are usually three or two part names listed with the family name first. Tan Suwi Siang is hence referenced as Tan, S. S. Malays and Indonesians are typically Muslim, and their names are usually in the form of first name, son/daughter of (bin/binte) second name, e.g., Idris bin Ali. Sometimes the middle is dropped, e.g., Idris Ali. Muslim names are often prefixed by an honorific, such as Muhammad (abbreviated Mohd or Muhd) or Haji. Hence, names are written and referenced in full. Thai names are presented in the usual first name, last name convention. Not all names are anglicised consistently (e.g., Sisuchat $v s$. Srisuchat in this paper) but to facilitate searching through databases the original spellings have been maintained.

1. Bland, W. Inscription on the Jetty at Singapur. J. Asiat. Soc. Bengal 1837, 6, 680-682.

2. Allirol, W.; Mol, B.P.J.C.; van Slooten, J.F.; Meijboom, W.; Deijl, S.J.A. Verslag van een bezoek op het eiland Klein-Kei door het Etat-Major van Z.M. Stoomschip Samarang. Tijdschr. Bataviaasch Genoot. Kunsten Wet. 1884, 29, 589-596.

3. Grabowsky, F. Kalksteinhoehlen in Suedost-Borneo. Globus 1888, 54, 326-329.

4. Kusch, H. Rock art discoveries in Southeast Asia: A historical summary. Boll. Cent. Camuno Stud. Preist. 1986, 23, 99-108.

5. Kerr, A.F.G. Note on some rockpaintings of eastern siam. J. Siam Soc. 1924, 18, 144-146.

6. Knuth, E. The oracle at Tambun: Malay and Thai paintings compared. Malays. Hist. 1962, 8, 3-10.

7. Lunet de La Jonquiere, É.E. Essai d'Inventaire Archaeologique du Siam; Bulletin de la Comission Archeologique du l'Indochine: Paris, France, 1912.

8. Van Heekeren, H.R. The Stone Age of Indonesia; Nijhoff: The Hague, The Netherlands, 1957.

9. Van Heekeren, H.R. The Bronze-Iron Age of Indonesia; Martinus Nijhoff: The Hague, The Netherlands, 1958.

10. Matthews, J.M. Rock paintings near Ipoh. Malaya Hist. 1959, 5, 22-25. 
11. Matthews, J.M. A note on the rock paintings recently discovered near Ipoh, Perak. Man 1960, 60, 1-3.

12. Harrisson, T. New archaeological and ethnological results from Niah Caves, Sarawak. Man 1959, 59, 1-8.

13. U Aung Thaw. The "Neolithic" culture of the Padah-lin Caves. Asian Perspect. 1971, 14, 123133.

14. Topics for Further Discussion. In SPAFA Final Report: Seminar in Prehistory of Southeast Asia; SEAMEO SPAFA: Bangkok, Thailand, 1987; pp. 333-336.

15. Taçon, P.S.C.; Tan, N.H. Recent Rock art Research in Southeast Asia and Southern China. In Rock Art Studies News of the World IV; Bahn, P., Franklin, N., Strecker, M., Eds.; Oxbow: Oxford, UK, 2012; pp. 207-214.

16. Anati, E. Word Rock Art: The Primordial Language, 3rd ed.; Edizioni del Centro: Capo di Ponte, Italy, 1994.

17. Clottes, J. World Rock Art; The Getty Conservation Institute: Los Angeles, CA, USA, 2002.

18. Chen, Z.F. Asia. In Handbook of Rock Art Research; Whitley, D.S., Ed.; Altamira Press: Walnut Creek, CA, USA, 2001; pp. 760-785.

19. Bellwood, P.; Glover, I. Southeast Asia: Foundations for an Archaeological History. In Southeast Asia: From Prehistory to History; Bellwood, P., Glover, I., Eds.; Routledge: London, UK, 2004; pp. 4-20.

20. Chaimongkhon, S. Sinlapa Tham Phi Hua To, Krabi (Ekkasan Kong Borannakhadi); Krom Sinlapakon: Bangkok, Thailand, 1990.

21. Charnwong, P. Sinlapa Tham Nai Isan; Krom Silpakorn: Bangkok, Thailand, 1988.

22. Khemnak, P. Sinlapa tham klum Ban Phu, Changwat Udon Thani; Fine Arts Department: Bangkok, Thailand, 1990.

23. Khemnak, P. Sinlapa Tham Samai Kon Prawattisat Nai Prathet Thai; Fine Arts Department: Bangkok, Thailand, 1996.

24. Khemnak, P.; Srisuchat, A.; Wongnoi, P.; Charoenwongsa, P. Sinlapa tham Sakon Nakhon; Silpakorn University: Bangkok, Thailand, 1989.

25. Sisuchat, T.; Khunthong, C. Sinlapa tham Khao Chan Ngam Nakhon Ratchasima; Krom Sinlapakon: Bangkok, Thailand, 1989.

26. Srisuchat, A. Rock Art of the Historic Period in Thailand; Thai Fine Arts Department: Bangkok, Thailand, 1992.

27. Srongsiri, W.; Sangchan, W. Phratu Pha, Lampang, Prehistorical Site, 3,000 Years Rock Painting Ceremony at the Sacred Cliff. In Art and Culture Magazine; Sujit Wongtate: Bangkok, Thailand, 1997.

28. Srisuchat, A. Rock Art News from South-East Asia. In Rock Art Studies News of the World I; Bahn, P.G., Fossati, A., Eds.; Oxbow Books: Oxford, UK, 1996; pp. 141-144.

29. Sidisunthorn, P.; Gardner, S.; Smart, D. Caves of Northern Thailand; River Books: Bangkok, Thailand, 2006.

30. Treerayapiwat, C. Patterns of habitation and burial activity in the ban rai rock shelter, Northwestern Thailand. Asian Perspect. 2005, 44, 231-245.

31. Sawatsalee, S. Rock Art Painting in Pang Mapha district, Mae Hong Son Province. M.A. Thesis; 
Silpakorn University, Bangkok, Thailand, 1998.

32. Kongsuwan, D. A study of Mortuary practice at Phratu Pha archaeological site, Mae Mo, Lampang. M. A. Thesis; Silpakorn University, Bangkok, Thailand, 2001.

33. Winayalai, C. Prehistoric rock art at Phratu Pha, Mae Moh, Lampang. Muang Boran 1998, 24, 117-122.

34. Winalayai, C. The study of Kai Phratu Pha rock painting site, Mae Mo district, Lampang province. M. A. Thesis; Silpakorn University, Bangkok, Thailand, 1999.

35. Santoni, M.; Pautreau, J.P.; Prishanshit, S. Excavations at Obluang, Province of Chiang Mai, Thailand. In Southeast Asian Archaeology; Glover, I., Glover, E., Eds.; In Proceedings of the first Conference of the Association of Southeast Asian Archeologist in Western Europe. Hands and Walker, Oxford BAR series 561: Oxford, England, 1990. pp. 37-54.

36. Pautreau, J.P.; Doy-Asa, T.; Matringhem, A.; Rodriguez-Lopez, E.; Souhaité, S. Art rupestre en Thaïlande. L'Archeol. Archeol. Nouv. 1996, 19, 12-15.

37. Pautreau, J.P.; Doy-Asa, T. L'abri-sous-roche de Pha Mai. Doss. d'Archeol. 2005, 302, 36-39.

38. Higham, C.; Thosarat, R. Early Thailand: From Prehistory to Sukhothai; River Books: Bangkok, Thailand, 2012.

39. Charoenwonsa, P. The Current Status of Prehistoric Research in Thailand. In Prehistoric Studies: The Stone and Metal Ages in Thailand, 1st ed.; Charoenwonsa, P., Bronson, B., Eds.; The Thai Antiquity Working Group: Bangkok, Thailand, 1988; Volume 1, pp. 17-41.

40. Munier, C. Sacred Rocks and Buddhist Caves in Thailand; White Lotus: Bangkok, Thailand, 1998.

41. Wang, N. An introduction to rock paintings in Yunnan Province (People's Republic of China). Rock Art Res. 1984, 1, 75-90.

42. Wang, N. Rock Paintings in Yunnan, China. Expedition 1985, 27, 25-33.

43. Yang, Y.Y. Ta Ke rock painting in Yuan Jiang county, Yunnan Province. SPAFA Dig. 1987, 8, 29-34.

44. Deng, Q. Rock Murals in Yunnan; Yunnan Publishing Group Corporation: Kunming, China, 2004.

45. Taçon, P.S.C.; Li, G.; Yang, D.; May, S.K.; Liu, H.; Aubert, M.; Ji, X.; Curnoe, D.; Herries, A.I.R. Naturalism, nature and questions of style in Jinsha river rock art, Northwest Yunnan, China. Camb. Archaeol. J. 2010, 20, 67-86.

46. Taçon, P.S.C.; Aubert, M.; Li, G.; Yang, D.; Liu, H.; May, S.K.; Fallong, S.; Ji, X.; Curnoe, D.; Herries, A.I.R. Uranium-series age estimates for rock art in southwest China. J. Archaeol. Sci. 2012, 39, 492-499.

47. Gao, Q. The huashan rock art site (China): The sacred meeting place for sky, water and earth. Rock Art Res. 2013, 30, 22-32.

48. Srisuchat, A.; Srisuchat, T. Sinlapa tham Kanchanaburi; Krom Sinlapakon: Bangkok, Thailand, 1989.

49. Knuth, E. The oracle at Tambun: Malay and Thai paintings compared. Malays. Hist. 1962, 8, 3-10.

50. Srisuchat, A. Sinlapa Tham Khao Plara, Uthai Thani; Krom Sinlapakon: Bangkok, Thailand, 1990. 
51. Chaimongkol, S. The planning team for the Southern Thailand cultural resource site preservation project prehistoric culture on the Andaman east coast. SPAFA Dig. 1988, 9, 28-33.

52. Scott, V.N. Interpretations of Ritual in the Rock-art of Kanchanaburi Province and Uthai Thani Province, Thailand. M.A. Thesis, School of Oriental and African Studies, University of London: London, UK, 2011.

53. Srisuchat, A. Prehistoric Cave and some Important Prehistoric Sites in Southern Thailand. In Final Report: Seminar in Prehistory of Southeast Asia; SEAMEO Project in Archaeology and Fine Arts: Bangkok, Thailand, 1987; pp. 103-117.

54. Richardson, J. Baedeker's Thailand; AA Publishing: Hampshire, UK, 1999.

55. Srisuchat, A. Sinlapa Tham Samai Prawattisat: Phak Klang, Phak Tai; Krom Sinlapakon: Bangkok, Thailand, 1991.

56. Sukkham, A.; Taçon, P.S.C.; Tan, N.H. Rock Art of Phrayanaga (Viking) Cave, Southern Thailand: The Illustration of Ancient Vessels. In Proceedings of the Asia-Pacific Regional Conference on Underwater Cultural Heritage, Manila, Philippines, 8-12 November 2011.

57. Blake, W. Drawings of ships in caves in Thailand. Bull. Aust. Inst. Marit. Archaeol. 1996, 20, 39-64.

58. Limwijitwong, S. Historic Rock Arts in the South of Thailand. In Proceedings of the Thailand-Malaysia: Malay Peninsular Archaeology Programme, Malaysia, Thailand, 4-10 September 2004; pp. 79-91.

59. Sukkham, A. Prehistoric Rock Painting at Yala Hill and Silpa Caves, Yala Province, Southern Thailand. In Proceedings of the 19th Congress of the Indo-Pacific Prehistory Association; Hanoi, Vietnam, 29 November-5 December 2009.

60. Sukkham, A. The dating of ancient rock arts in Southern Thailand. M.A. Thesis, Silpakorn University, Bangkok, Thailand, 2010.

61. Heng, S.; Tep, S.; Em, D.; Son, C. Rock painting at cardamom mountains, Cambodia. SPAFA J. 2011, 21, 21-27.

62. Tep, S.; Em, D.; Son, C. Report on Rock Cave Painting at Kanam Village, Kravan District, Pursat. Phnom Penh, Cambodia, 2011.

63. Beavan, N.; Halcrow, S.; McFadgen, B.; Hamilton, D.; Buckley, B.; Tep Sokha; Shewan, L.; Ouk Sokha; Fallon, S.; Miksic, J.; et al. Radiocarbon dates from jar and coffin burials of the cardamom mountains reveal a unique mortuary ritual in Cambodia's late- to post- Angkor Period (15th-17th centuries AD). Radiocarbon 2012, 54, 1-22.

64. Heng, T. Kulen mountain rock art: An initial assessment. SPAFA J. 2011, 21, 29-34.

65. Heng, T. Kulen Mountain Rock Art. Presented at the Training/Workshop on the Introduction to Rock Art Studies in Southeast Asia, Bangkok, Thailand, 2-13 May 2011.

66. Taçon, P.S.C. Kulen Mountain rock art: An initial assessment and report to APSARA, Siem Reap, Cambodia. In PERAHU, School of Humanities: Gold Coast, Australia, 2011.

67. Boulbet, J.; Dagens, B. Les sites archeologiques de la region du bhnam gulen (Phnom Kulen). Arts Asiatiques 1973, 27.

68. Jessup, H.I. The Rock Shelter of Peuong Kumnu and Visnu Images on Phnom Kulen. In Interpreting Southeat Asia's Past: Monument, Image and Text; Bacus, E.A., Glover, I.C., Sharrock, P.D., Eds.; NUS Press: Singapore, Singapore, 2008; Volume 2, pp. 184-192. 
69. Tan, N.H.; Taçon, P.S.C. Rock Art and the Sacred Landscapes of Mainland Southeast Asia. In Rock Art and Sacred Landscapes; Gillette, D., Breen Murray, W., Greer, M., Helene Hayward, M., Eds.; Springer Science: New York, NY, USA, 2014.

70. Bouxaythip, S. The Significant Rock Art in the Lao P.D.R. Presented at the Training/Workshop on the Introduction to Rock Art Studies in Southeast Asia, Bangkok, Thailand, 2-13 May 2011.

71. Tan, N.H.; Walker, V. The Curious Case of the Steamship on the Mekong. In Proceedings of the 2nd International Contact Rock Art Symposium, Darwin, Australia, 13-15 September 2013; Available online: http://www.academia.edu/4523409/The_Curious_Case_of_the_Steamship_ on_the_Mekong (accessed on 29 September 2013).

72. Colani, M. Megalithes du Haut-Laos; Les Editions d'Art et d'Histoire: Paris, Frane, 1935.

73. Moore, E.H. Early Landscapes of Myanmar; River Books: Bangkok, Thailand, 2007.

74. Taçon, P.S.C.; Aung, D.Y.Y.; Thorne, A. Myanmar prehistory: Rare rock-markings revealed. Archaeol. Ocean. 2004, 39, 138-139.

75. Gutman, P.; Hudson, B.; Htin, K.M.; Aung, K.T. Rock art and artisans in the Lemro Valley, Arakan, Myanmar. Antiquity 2007, 81, 655-674.

76. U Win Kyaing. The Hypothetical Approach on the Prehistoric Rock Art Study in Myanmar. Presented at the Training/Workshop on the Introduction to Rock Art Studies in Southeast Asia, Bangkok, Thailand, 2-13 May 2011.

77. Datan, I. Cave Drawings. In Encyclopedia of Malaysia: Early History; Abdul Rahman, N.H.S.K., Ed.; Archipelago Press: Singapore, Singapore, 1998; Volume 4, pp. 42-43.

78. Adi Haji Taha.; Zulkifli Jaafar Rock arts in Peninsular Malaysia. In Proceedings of the ThailandMalaysia: Malay Peninsular Archaeology Programme, Malaysia, Thailand, 4-10 September 2004.

79. Sanim Ahmad. Lukisan primtif gua batu kapur Malaysia II. J. Arkeologi Malays. 2006, 19, 1526.

80. Evans, I.H.N. Preliminary report on cave explorations, near lenggong, upper perak. J. Fed. Malay.States Mus. 1918, 7, 227-234.

81. Evans, I.H.N. Negrito cave drawings at lenggong, upper perak. J. Fed. Malay. States Mus. 1927, $12,105-106$.

82. Williams-Hunt, P.D.R. An Introduction to the Malayan Aborigines; Government Press: Kuala Lumpur, Malaysia, 1952.

83. Faulstich, P. From Ashes to Gravestones: The Charcoal Drawings of Gua Badak, Malaysia. In Rock Art and Posterity; Pearson, C., Swartz, B.K.J., Eds.; Australian Rock Art Association: Melbourne, Australia, 1988; pp. 24-27.

84. Mokhtar Saidin.; Taçon, P.S.C. The recent rock drawings of the Lenggong Valley, Perak, Malaysia. Antiquity 2011, 85, 459-475.

85. Adi Haji Taha. Recent archaeological discoveries in Peninsular Malaysia (1987-1990). J. Malays. Branch R. Asiat. Soc. 1991, 64, 75-96.

86. Abdul Latib Ariffin. Penyelidikan lukisan lama di gua luas, batu luas (kuala kenyam), ulu tembeling, pahang. Malay. Nat. 1985, 38, 38-43.

87. Zulkifli Jaafar. Ancient Limestone Landscapes of Malaysia: An Archaeological Insight;

Department of Museums and Antiquities: Kuala Lumpur, Malaysia, 2003. 
88. Adi Haji Taha. Recent archaeological discoveries in Peninsular Malaysia (1991-1993). J. Malays. Branch R. Asiat. Soc. 1993, 66, 67-83.

89. Ong, J. Mysterious Caves of Langkawi, Malaysia; Department of Irrigation and Drainage, Ministry of Agriculture: Kuala Lumpur, Malaysia, 1994.

90. Tan, N.H. Scientific Reinvestigation of the rock art at Gua Tambun, Perak. Volume 1: New Research. M.A. Thesis, Universiti Sains Malaysia: Penang, Malaysia, 2010.

91. Tan, N.H. Scientific Reinvestigation of the rock art at Gua Tambun, Perak. Volume 2: Inventory of Rock Art. M.A. Thesis, Universiti Sains Malaysia: Penang, Malaysia, 2010.

92. Tan, N.H.; Chia, S. 'New' rock art from gua tambun, perak, Malaysia. Rock Art Res. 2010, 27, 9-18.

93. Goloubew, V. Roches gravées dans la région de Chapa. Bull. l'Ecole Franç. d'Extrême-Orient 1925, 25, 423-433.

94. Sapa ancient carved rock field to be introduced in Sweden. Vietnam Net. 2009. Available online: http://english.vietnamnet.vn/lifestyle/2009/07/859895/ (accessed on 25 July 2009).

95. Trinh, N.C. Nhung Hinh Khac Co Tren Da O Xin Man, Ha Giang. Khao Go 2007, 149, 76-84.

96. 2,000 year-old megalith uncovered in Tam Dao. Vietnam Net. 2009. Available online: http://english.vietnamnet.vn/tech/2009/05/848883/ (accessed on 29 May 2009).

97. Nguyen, T.T.; Dinh, N.T. Discovery and Research of Megalith Sites in Soc Son (Ha Noi Vietnam). Presented at the Training/Workshop on the Introduction to Rock Art Studies in Southeast Asia, Bangkok, Thailand, 2-13 May 2011.

98. Ancient farm tools help dig up the past. Vietnam News 2012. Available online: http://vietnamnews.vn/Life-Style/229918/ancient-farm-tools-help-dig-up-the-past.html (accessed on 28 April 2013).

99. Prehistoric cave drawings found in Ha Giang. Vietnam Net 2013. Available online: http://english.vietnamnet.vn/fms/art-entertainment/85451/prehistoric-cave-drawings-found-in-hagiang.html (accessed on 4 October 2013).

100. Laidlay, J.W. Note on the Inscriptions from Singapore and Province Wellesley Forwarded by the Hon. Col Butterworth and Col J. Low. J. Asiat. Soc. Bengal 1848, 17, 66-72.

101. Prinsep, J. Inscription at Singapore. J. Asiat. Soc. Bengal 1848, 17, 154-155.

102. Abdullah bin Abdul Kadir. The Hikayat Abdullah; Oxford University Press: Kuala Lumpur, Malaysia, 1970.

103. Blust, R. The prehistory of the austronesian-speaking peoples: A view from language. J. World Prehist. 1995, 9, 453-510.

104. Kosasih, E.A. Rock Art in Indonesia. In Rock Art and Prehistory; Bahn, P., Rosenfeld, A., Eds.; Oxbow Books: Oxford, UK, 1991; Volume 10, pp. 65-77.

105. Van der Hoop, A.N.J.T.à.T. Megalithic remains in South-Sumatra; Thieme: Zutphen, The Netherlands, 1932.

106. Vonk, H.W. De "batoe tatahan" bij Air Poear (Pasemah-landen). Tijdschriff Indische Taal-, Land- en Volkenkd. 1934, 74, 296-300.

107. Caldwell, I. A rock carving and a newly discovered stone burial chamber at Pasemah, Sumatra. Bijdr. Taal-, Land-en Volkenkd. 1997, 153, 169-182.

108. Schnitger, F.M.; Tichelman, G.L. Forgotten Kingdoms in Sumatra; Oxford University Press: 
Oxford, UK, 1989.

109. Megalithic site found in South Sumatra. Jakarta Post 2010. Available online: http://www.thejakartapost.com/news/2010/02/17/megalithic-site-found-south-sumatra.html (accessed on 28 April 2013).

110. Megalithic site found in South Sumatra. Jakarta Post 2011. Available online: http://www.thejakartapost.com/news/2011/01/18/megalithic-site-found-south-sumatra.html (accessed on 28 April 2013).

111. Caldwell, I.; Hazlewood, A.A. The holy footprints of the venerable Gautama; A new translation of the Pasir Panjang inscription. Bijdr. Taal-, Land-en Volkenkd. 1994, 150, 457-480.

112. Bonatz, D.; Neidel, J.D.; Tjoa-Bonatz, M.L. The megalithic complex of highland Jambi: An archaeological perspective. Bijdr. Taal-, Land-en Volkenkd. 2006, 162, 490-522.

113. Simanjuntak, T. Research Progress on Austronesian Studies in Indonesia. Presented at the 19th Congress of the Indo-Pacific Prehistory Association, Hanoi, Vietnam, 29 Nov-5 Dec 2009.

114. Steinmetz, H.E. Oudheidkundige beschrijving van de afdeeling Bandawasa (Residentie Besoeki). Tijdschriff Indische Taal-, Land- en Volkenkd. 1898, 40, 1-60.

115. Van Heekeren, H.R. Megalithische overblijfselen in Besoeki, Java. Djawa 1931, 11, 1-18.

116. Flines, E.W.V.O.D. Hasin-Medang-Kuwu-Lang-piya. Tijdschriff Indische Taal-, Land- en Volkenkd. 1949, 83, 424-429.

117. De Haan, B. Rapport over de werkzaamheden op Oost-Java. Oudheidkd. Versl. 1921, , 55-59.

118. Djubiantono, T.; Morwood, M.J.; Agus Batu Tulis: A petroglyph site in west Java, Indonesia. Rock Art Res. 2001, 18, 113-114.

119. Chazine, J.M. Rock Art and Ceramics in East Borneo: Logical Discovery or New Cornerstone? In Pacific Archaeology: Assessments and Prospects; Sand, C., Ed.; Publication du Département d'Archéologie: Nouméa, France, 2003; pp. 43-52.

120. Chazine, J. Rock art, burials and habitations: Caves in East Kalimantan. Asian Perspect. 2005, 44, 219-230.

121. Chazine, J.-M. Recent Rock Art and Archaeological Discoveries in East Kalimantan-Indonesia. Presented at the CNRS-CREDO/MAP Yogyakarta Conference, Yogyakarta, Indonesia, 24-29 September 2005.

122. Chazine, J.-M. Decoding the hands. Natl. Geogr. 2005, 208, 43-44.

123. Chazine, J.M. Discovering a New Rock art in Borneo: New Data and Concerns. In World of Rock Art Conference Pre-Proceedings; Devlet, E., Ed.; Institute of Archaeology of the Russian Academy of Sciences: Moscow, Russia, 2005; pp. 319-334.

124. Fage, L.-H. Hands across time. Natl. Geogr. 2005, 208, 32-42.

125. Plagnes, V.; Causse, C.; Fontugne, M.; Valladas, H.; Chazine, J.-M.; Fagec, L.-H. Cross dating (Th/U-14C) of calcite covering prehistoric paintings in Borneo. Quartenary Res. 2003, 60, 172-179.

126. Taçon, P.S.C.; Tan, N.H.; O’Connor, S.; Ji, X.; Li, G.; Curnoe, D.; Bulbeck, D.; Hakim, B.; Sumantri, I.; Heng, T.; et al. Global implications of early surviving rock art of Southeast Asia. (In preparation).

127. Akin Duli. Makna simbolis beberapa motif goresan pada situs megalitik tinco dan lawo di kabupaten soppeng. WalennaE J. Arkeol. Sulawesi Selatan Tenggara 2002, 9, 33-39.

128. Retno Handini. Menhir in the Exoticism of Toraja, South Sulawesi: A Living Megalithic 
Tradition. In 11th International Conference of the European Association of Southeast Asian Archaeologists, Bougon; Pautreau, J.-P., Coupey, A.-S., Zeitoun, V., Rambault, E., Eds.; 11th International Conference of the European Association of Southeast Asian Archaeologists: Bougon,

2006; pp. 273-278.

129. Ballard, C. Dudumahan: A rock art site on kai kecil, southeast moluccas. Bull. Indo-Pacific Prehist. Assoc. 1988, 8, 139-161.

130. Röder, J. Felsbilder auf ceram. Paideuma 1938, 1, 19-28.

131. Latinis, K.; Stark, K. Cave use variability in central maluku, eastern Indonesia. Asian Perspect. 2005, 44, 119-136.

132. Made Arya Kencana 2,500-Year-Old Human Remains Discovered in Bali. Jakarta Globe 2010. Available online: http://www.thejakartaglobe.com/archive/2500-year-old-human-remainsdiscovered-in-bali/393524/ (accessed on 19 August 2013).

133. Sertori, T. Bali's ancient history at 10 cents a brick. Jakarta Post 2009. Available online: http://www.thejakartapost.com/news/2009/02/05/bali039s-ancient-history-10-cents-a-brick.html (accessed on 19 August 2003).

134. Verhoeven, T. The Watu Weti (picture rock) of Flores. Anthropos 1956, 51, 1077-1079.

135. Röder, J. The rockpaintings of the Mac Cluer Bay (Western New Guinea). Antiq. Surv. 1956, 1, 387-400.

136. Souza, C.R.; Solheim, W.G., II. A New Area of Rock Paintings in Irian Jaya, Indonesian New Guinea. In Rock-Art of India; Chakravarty, K.K., Ed.; Arnold-Heinemann: Madhya Pradesh, Bhopal, 1984; pp. 182-195.

137. Chazine, J. Exclusif: Des peintures rupestres fascinantes découvertes en Papouasie. Available online: http://www.futura-sciences.com/magazines/sciences/infos/actu/d/homme-exclusif-peinturesrupestres-fascinantes-decouvertes-papouasie-14195/ (accessed on 24 August 2013).

138. Keller, N. Ethno-archaeology Mission Report. Available online: http://www.precious-planet.org/ en/news/news4.html (accessed on 24 August 2013).

139. Nugent, S. News from WAC Members. Available online: http://www. worldarchaeologicalcongress.org/site/newsletters_20.php (accessed on 24 August 2013).

140. Pyatt, F.B.; Wilson, B.; Barker, G.W. The chemistry of tree resins and ancient rock paintings in the Niah Caves, Sarawak (Borneo): Some evidence of rain forest management by early human populations. J. Archaeol. Sci. 2005, 32, 897-901.

141. Datan, I. Archaeological Excavations at Gua Sireh (Serian) and Lubang Angin (Gunung Muluh National Park), Sarawak, Malaysia. Sarawak Mus. J. 1993, 45, 1-191.

142. Harrisson, T.; Reavis, J.L. The sarang caves in sarawak. Sarawak Mus. J. 1966, 14, 249-268.

143. Chia, S. Archaeological Research at Bukit Sarang Caves, Ulu Kakus, Sarawak. 2009. Available online: http://eprints.usm.my/7732/ (accessed on 24 August 2013).

144. Majid, Z. Archaeology in Malaysia; Pusat Penyelidikan Arkeologi Malaysia, Universiti Sains Malaysia: Penang, Malaysia, 2003.

145. Bellwood, P. Archaeological Research in South-Eastern Sabah; Sabah Museum and State Archives: Kota Kinabalu, Malaysia, 1988; Volume 2.

146. Hasan, A.S. Prehistoric Painting in Borneo: Colors from the Earth's Core. In Seminar on the 
Prehistory of Borneo; Miri: Sarawak, Malaysia, 2010.

147. Harrisson, T. Newly discovered prehistoric rock carvings-Ulu Tomani, Sabah. J. Malays. Branch R. Asiat. Soc. 1973, 47, 141-143.

148. Harrisson, T.; Harrisson, B. The prehistory of Sabah. Sabah Soc. J. 1969-1970, 4.

149. Harrisson, T.; O'Connor, S., Jr. The prehistoric iron industry in the Sarawak River delta: Evidence by association. Sarawak Mus. J. 1968, 16, 1-54.

150. Tacon, P.S.C.; Datan, I.; Sauffi, M.S. New engravings discovered at Santubong, Sarawak, Malaysia. Sarawak Mus. J. 2010, 67, 105-121.

151. Harrisson, T. Megalithic evidences in east Malaysia: An introductory summary. J. Malays. Branch R. Asiat. Soc. 1973, 47, 123-139.

152. Phelan, P.R. Traditional Stone and Wood Monuments of Sabah; Pusat Kajian Borneo: Kota Kinabalu, Malaysia, 1997.

153. Datan, I. Earthen Crocodile Effigies (Buaya Tanah) of Sarawak: A Preliminary Report. In Seminar on the Prehistory of Borneo; Miri: Sarawak, Malaysia, 2010.

154. Lloyd-Smith, L.; Datan, I. Current Research on the Megaliths of the Kelabit Highlands, Sarawak. In Seminar on the Prehistory of Borneo; Miri: Sarawak, Malaysia, 2010.

155. Azlin Samsudin; Ratna Mohd Rapi; Faridah Hanim; Jeffrey Abdullah; Molijol, P. Spatial Analyst and Database Management of Megalith in Penampang and Kinarut, Sabah. In Seminar on the Prehistory of Borneo; Miri: Sarawak, Malaysia, 2010.

156. Ratna Wati binte Mohd Rapi; Azlin Samsudin; Siti Faridah Hanim; Jeffrey Abdullah; Molijol, P. Preliminary Study of Megaliths in the area of Penampang and Kinarut, Sabah. In Seminar on the Prehistory of Borneo; Miri: Sarawak, Malaysia, 2010.

157. De Almeida, A. A Contribution to the Study of Rock Paintings in Portuguese Timor. In Proceedings of the Archaeology at the Eleventh Pacific Science Congress: Papers Presented at the XI Pacific Science Congress, Tokyo, Japan, August-September 1966. In Asian and Pacific Archaeology Series; W. G. Solheim II., Ed. Social Science Research Institute, University of Hawaii: Honolulu, HI, USA, 1967; Volume 1, pp. 69-76.

158. Glover, I. Archaeology in Eastern Timor, 1966-67. In Terra Australis 11; Department of Prehistory, Research School of Pacific Studies, Australian National University: Canberra, Australia, 1986.

159. O’Connor, S. Nine new painted rock art sites from East Timor in the Context of the Western Pacific Region. Asian Perspect. 2003, 42, 96-128.

160. O'Connor, S.; Olivera, N.V. Inter- and intraregional variation in the austronesian painting tradition: A view from east timor. Asian Perspect. 2007, 46, 389-403.

161. Lape, P.V.; O’Connor, S.; Burningham, N. Rock art: A potential source of information about past maritime technology in the south-east asia-pacific region. Int. J. Nautical Archaeol. 2007, $36,238-253$.

162. Aubert, M.; O’Connor, S.; McCulloch, M.; Mortimer, G.; Watchman, A.; Richer-LaFlèche, M. Uranium-series dating rock art in East Timor. J. Archaeol. Sci. 2007, 34, 991-996.

163. O’Connor, S.; Aplin, K.; Pierre, E.S.; Feng, Y.-X. Faces of the ancestors revealed: Discovery and dating of a Pleistocene-age petroglyph in Lene Hara Cave, East Timor. Antiquity 2010, 84, 649-665. 
164. Forestier, H.; Guillaud, D. A Limestone Outcrop as a Landmark of Prehistoric Settlement in the Manatuto Region (East Timor). In Unearthing Southeast Asia's Past: Selected Papers from the 12th International Conference of the European Association of Southeast Asian Archaeologists, Klokke, M.J., Degroot, V., Eds.; NUS Press: Singapore, Singapore, 2013; pp. 26-33.

165. Barretto-Tesoro, G. A review of the angono petroglyphs. Test Pit 2008, 13, 19-24.

166. Peralta, J.T. Tau't Batu Studies; National museum and the Presidential Association on National Minorities: Manila, Philippines, 1983.

167. Peralta, J.T. Preliminary Report on the Petrographs of the Penablanca Caves; National Museum of the Philippines: Manila, Philippines, 1997.

168. National Commission for Culture and the Arts Petroglyphs and Petrographs of the Philippines. 2006. Available online: http://whc.unesco.org/en/tentativelists/5018/ (accessed on 3 November 2008).

169. Faulstich, P. X-ray rock art of Australia and Southeast Asia. Boll. del Centro Camuno di Studi Preistorici 1990, 25-26, 123-132.

170. Chazine, J.-M.; Ferrié, J.-G. Recent archaeological discoveries in east Kalimantan, Indonesia. IPPA Bull. 2008, 28, 16-22.

171. Ballard, C. Painted Rock Art Sites in Western Melanesia: Locational Evidence for an 'Austronesian' Tradition. In State of the Art: Regional Rock Art Studies in Australia and Melanesia; McDonald, J., Haskovec, P., Eds.; Australian Rock Art Research Association: Melbourne, Australia, 1992.

172. Gullick, J.M. A History of Negri Sembilan; Malaysian Branch of the Royal Asiatic Society: Kuala Lumpur, Malaysia, 2003; Volume 33.

173. Meacham, W. Rock Carvings in Hong Kong; William Meacham: Hong Kong, China, 2009.

(C) 2014 by the authors; licensee MDPI, Basel, Switzerland. This article is an open access article distributed under the terms and conditions of the Creative Commons Attribution license (http://creativecommons.org/licenses/by/3.0/). 